\title{
Austerity and Anarchy: \\ Budget Cuts and Social Unrest in Europe, 1919-2008
}

\author{
Jacopo Ponticelli Hans-Joachim Voth*
}

\begin{abstract}
Does fiscal consolidation lead to social unrest? Using cross-country evidence for the period 1919 to 2008, we examine the extent to which societies become unstable after budget cuts. The results show a clear correlation between fiscal retrenchment and instability. Expenditure cuts are particularly potent in fueling protests; tax rises have only small and insignificant effects. We test if the relationship simply reflects economic downturns, using a recently-developed IMF dataset on exogenous expenditure shocks, and conclude that this is not the case. While autocracies and democracies show broadly similar responses to budget cuts, countries with more constraints on the executive are less likely to see unrest after austerity measures. Growing media penetration does not strengthen the effect of cut-backs on the level of unrest. We also find that austerity episodes that result in unrest lead to quick reversals of fiscal policy.
\end{abstract}

*Ponticelli: UPF (jacopo.ponticelli@upf.edu); Voth: ICREA/UPF and CREI (jvoth@crei.cat). We thank Alberto Alesina, Silvia Ardagna, Carlo Favero, and Francesco Giavazzi for sharing their data, and Olivier Blanchard, Vasco Carvalho, Mario Diani, Jordi Galí, Nicola Gennaioli, Tim Leunig, Kris Mitchener, Federico Todeschini, Alan Taylor, and Carlos Vegh for comments on the paper and the project at large. Seminar audiences at the 2011 EHA meetings, the 2010 Bank of Chile Fiscal Policy Conference, Chatham House, the 2012 INET Conference in Berlin, and at CREI offered feedback. Financial support by the European Research Council and the Barcelona GSE is gratefully acknowledged. 


\section{Introduction}

From the French Revolution to the Arab Spring, social unrest has led to key turning points in history. Marx saw it as the driving force of the transition of societies from feudalism to capitalism and, eventually, communism. The power of unrest as a catalyst for change manifests itself explicitly in regime changes, or it operates through expectations: The extension of the franchise in Western societies can be seen as a bid to reduce the threat of revolution (Acemoglu and Robinson, 2000). ${ }^{1}$ What leads to social unrest is less clear. Economic shocks are one possible contributing factor: The demise of the Weimar Republic at the height of the Great Depression is a prominent example of economic hardship translating into political instability and social unrest (Bracher, 1978). ${ }^{2}$

In this paper, we examine one of the possible determinants of unrest and violent protests - fiscal policy. How do budget measures affect the level of social instability? The extent to which societies fracture and become unstable in response to drastic retrenchment in the government budget is a major concern for policymakers tackling large budget deficits: To name but two examples, in both Argentina in 2001 and in Greece in 2010-11, austerity measures often coincide with waves of protest and civil unrest. Economic conditions can deteriorate further and faster if political and social chaos follows attempts to reign in spending. ${ }^{3}$ Consequently, sustainable debt levels for countries that are prone to unrest may be lower than they otherwise would be.

Using a panel dataset for 25 European countries covering the period 1919 to 2008 , we show a clear link between the magnitude of expenditure cut-backs and increases in social unrest. With every additional percentage point of GDP in spending cuts, the risk of unrest increases. This finding is surprising in the light of the recent political economy literature on expenditure cuts. Alesina et al. (1998, 2010) show that governments typically do not lose votes in elections after they implement austerity programs (and relatedly, there is no electoral benefit for free-spending parties (Brender and Drazen, 2008). The fact that austerity may lead to unrest - even without penalties at the ballot box - may help to explain why governments are typically reluctant to cut spending, even if this might be economically beneficial. ${ }^{4}$

Europe over the last century is an an ideal testing ground for our hypthesis. The continent went from high levels of instability in the first half of the 20th century to

\footnotetext{
${ }^{1}$ In a related exercise, Boix (2003) models the incentives of the populace to resort to violence as a function of the wealth distribution and economic development.

${ }^{2}$ The French Revolution has also been interpreted in these terms (Soboul, 1974; Doyle, 2001). The view is controversial (Hunt, 2004; Cobban, 1964).

${ }^{3}$ Bloom (2009) documents how uncertainty shocks can reduce output.

${ }^{4}$ Alesina and Ardagna (2010); Alesina et al. (2002); Guajardo et al. (2011). An early example in the literature is Giavazzi and Pagano (1990). The finding is controversial - cf. Devries et al. (2011).
} 
relatively low ones in the second, and from frequently troubled economic conditions to prosperity. It thus provides a rich laboratory of changing economic, social and political conditions. In terms of outcome variables, we focus on riots, demonstrations, political assassinations, government crises, and attempted revolutions. These span the full range of forms of unrest, from relatively minor disturbances to armed attempts to overthrow the established political order. We compile a new index that summarizes these variables, and then ask - for every percentage cut in government spending, how much more instability should we expect?

As a first pass at the data, Figure 1 shows the relationship between fiscal adjustment episodes and the number of incidents indicating instability (CHAOS). CHAOS is the sum of demonstrations, riots, strikes, assassinations, and attempted revolutions in a single year in each country. The first set of five bars show the frequencies conditional on the size of budget cuts. When expenditure is increasing, the average country-year unit of observation in our data registers less than 1.4 events. For moderate budget cuts, there is no increase in the frequency of unrest. However, as austerity intensifies, the frequency of disturbances rises. Above 3\%, the frequency of events rises markedly. Once austerity measures involve expenditure reductions by $5 \%$ or more, there are around 4 events per year and country - more than twice as many as in times of expenditure increases or mild cuts.

\section{[Figure 1 here]}

The same relationship can be observed in each of the four main subcategories of CHAOS. The frequency of riots, demonstrations, political assassinations, and general strikes is greatest for the biggest cuts. While small cuts have few effects, beyond a certain threshold, unrest explodes.

The strength of the link between austerity measures and unrest is our first important finding. Is the link causal? Other factors, such as generally depressed economic conditions, have the potential to drive up unrest and the need for cut-backs simultaneously. Controlling for economic growth does not change our results. This suggests that we capture more than a general association between economic downturns and unrest. Also, controlling for ethnic fragmentation and unemployment does not change our result. Findings are robust to adding other possible tools available to governments to finance public deficit as controls: inflation and public debt.

To demonstrate that causality runs from cut-backs to unrest, we use recently compiled data on changes in the government budget that follow directly from discretionary policy decisions (Devries et al., 2011). ${ }^{5}$. In addition, we draw on the work by Alesina

\footnotetext{
${ }^{5}$ The recent work by Devries et al. (2011) follows in the footsteps of Romer and Romer (1989, 2010). For a critique of the application to US fiscal policy after 1945, cf. Ramey (2011)
} 
et al. (2012) that decomposes changes in the government budget that follow directly from discretionary policy decisions into their anticipated and unanticipated components. For both types of additional evidence, we find clear indications that the link runs from budget cuts to unrest.

Our findings are robust to a wide range of alternative specifications and further tests. Different measures of unrest do not affect our conclusions. We examine if the link between austerity and unrest changes as countries institutions improve. For most values of the Polity2 score of institutional quality, results are broadly constant. However, countries with very high levels of constraints on the executive show a somewhat weaker degree of association. Further, we examine if the spread of mass media changes the probability of unrest. This is not the case. If anything, higher levels of media availability and a more developed telecommunications infrastructure reduce the strength of the mapping from budget cuts to instability. We also test which part of the distribution of unrest is responsible for our results, using quantile regressions: The higher the level of unrest, the bigger the relative impact of additional budget cuts. Finally, we test for asymmetries in the relationship between unrest and austerity. Reductions increase instability, but spending increases do not cut the number of incidents to the same extent.

Earlier papers have typically focussed on case studies, on relatively short timeperiods, or on subsets of the developing world. ${ }^{6}$ DiPasquale and Glaeser (1998) analyzed race riots in the US in the 1960s and early 1990s. ${ }^{7}$ They find that ethnic heterogeneity and unemployment rates are a strong predictors of riots, and that poverty is relatively unimportant. Bohlken and Sergenti (2010) argue that riot probabilities in India over the period 1982-95 dropped sharply when growth rates accelerated. Field et al. (2008) examine religious violence in Ahmedabad, India, in 2002, and argue that tenancy rights created neighborhoods that were more integrated, and hence more prone to violence.

Comparative work by Alesina and Perotti (1996) suggests that inequality leads to more unrest, and this instability can adversely affect investment. Work on 23 African countries during the 1980s found that budget cuts had typically no effect on political and social stability. IMF interventions, on the other hand, often led to more frequent disturbances (Morrison et al., 1994). Paldam (1993) examines current account crises in seven South American countries during the period 1981-90, using high-frequency (weekly) data. He finds that the run-up to new austerity measures is associated with higher levels of unrest, but that actual implementation is followed by

\footnotetext{
${ }^{6}$ Theoretical work on unrest includes Kuran (1989), Tullock (1971), and Grossman (1991).

${ }^{7}$ The authors also analyse international data for the period 1960-85. They find that higher GDP reduces the incidence of riots, while urbanization rates are positively associated with them.
} 
fewer disturbances. Similarly, Haggard et al. (1995) find that IMF interventions and monetary contractions in developing countries led to greater instability. Analyzing the period 1937-1995, Voth (2011) explores related issues for the case of Latin America. He finds that austerity and unrest are tightly linked in a majority of cases. ${ }^{8}$ Martin and Gabay (2012) analyze fiscal protests in a set of European countries after 1980, and argue that incompatibilities between tax and spending policies are responsible for popular opposition. Andronikidou and Kovras (2012) focus on cultural determinants of differential inclinations to protest.

Relative to these papers, we make several contributions. To the best of our knowledge, ours is the first systematic analysis of how budget cuts affect the level of social instability and unrest in a broad cross-section of developed countries, over a long period. We also examine the exact causes of instability in a subset of the data where more detailed information is available, and find a strong link with austerity. This also allows us to perform placebo tests. Using detailed evidence on the motivations for government expenditure changes, we strengthen the causal link still further. Finally, we examine the link between instability and media penetration.

Other related literature includes work on the political economy of fiscal consolidation and its economic effects, as well as the logic of conflict between politicians and society. Recent work has emphasised that cutting entitlement programs tends to produce persistent improvements in the budget balance, while revenue measures and capital expenditure cuts have only temporary effects (Alesina and Perotti, 1995). The timing of stabilization measures has been explored in war-of-attrition models, which view relative bargaining strength of different groups as crucial (Alesina and Drazen, 1991). A rich literature has examined the macroeconomic effects of budget cuts. Giavazzi and Pagano (1990) and Alesina et al. (2002) find that cuts can be expansionary. Amongst the reasons suggested for this finding are a reduction in uncertainty about the course future spending (Blanchard, 1990a), and a positive wealth shock as a result of lower taxes in the future (Bertola and Drazen, 1993). ${ }^{9}$ Recently, work by the IMF has suggested that austerity measures may be less expansionary than previously thought; they may well have the standard negative Keynesian effects as a result of lower demand (IMF, 2010; Guajardo et al., 2011).

We also relate to the rich literature on conflict between the government and society at large. Persson et al. (1997) argue that the separation of powers in modern constitutions is deliberately designed to engineer conflict, preventing the abuse of power. It could be argued that "direct action" in the form of demonstrations and extra-legal

\footnotetext{
${ }^{8}$ There is also a rich literature on economic instability and political radicalization, which we cannot survey here. For a recent analysis of the interwar period, cf. De Bromhead et al. (2012).

${ }^{9}$ Once the response of labor supply and capital formation is fully taken into account, these effects may not go through (Baxter and King, 1993).
} 
means such as riots act as an extreme form of "checks and balances" on the executive. Other related work that also treats the issue of conflict between government and governed includes the work of Buchanan and Tullock (1962), Ferejohn (1986), Shleifer and Vishny (2002).

The paper is structured as follows: Section 2 presents our data, and section 3 summarises our main results. Robustness checks and extensions are discussed in section 4 ; section 5 concludes.

\section{Data}

In this section, we briefly describe our data and summarize its main features. Five main indicators of domestic conflict in the long-term data form the main basis of this study - general strikes, riots, anti-government demonstrations, political assassinations, and attempted revolutions. These data are part of the Cross National Time Series Dataset, compiled by Banks (2010) and his collaborators. The main source of data on unrest episodes are the reports of the The New York Times, while the variables' definition is adopted from Rummel and Tanter (1971). In addition, we use data on GDP, government revenue, expenditure, and the budget balance from a variety of sources. ${ }^{10}$ The dataset contains information on 25 European countries and covers the years from 1919 to $2008 .^{11}$

Table 1 gives an overview of the main variables and their descriptive statistic for the long-term data. The average number of assassinations and general strikes was quite low in our sample, with less than 2 events in each decade. There were more riots and more demonstrations, 5-6 per decade. Attempted revolutions are quite rare, but some countries registered high levels of instability. The record in our sample is Germany in 1923, with 5 recorded attempts at overthrow (with communist insurgencies in Saxony and Thuringia, the Hitler Beer Hall Putsch, and a separatist movement in the Rhineland). Assassinations and riots similarly show a broad range of observed values. Almost a century of data includes some extreme observations. ${ }^{12}$ For example, Austria and Germany saw major output declines in 1945 and 1946, respectively. The biggest reduction in governments spending in our data occurred in Poland, in 1982; the second-largest, in Finland, in 1947. The start of wars is often associated with big increases in expenditure. The record-holder in our dataset is Hungary in 1940, with

\footnotetext{
${ }^{10}$ See the Data Appendix for a detailed description of the sources of each variable

${ }^{11}$ The countries included are: Austria, Belgium, Bulgaria, Cyprus, Czech Republic, Denmark, Estonia, Finland, France, Germany, Greece, Hungary, Ireland, Italy, Netherlands, Norway, Poland, Portugal, Russian Federation, Slovak Republic, Spain, Sweden, Switzerland, United Kingdom, Yugoslavia.

${ }^{12}$ In the data appendix we explain in detail how we deal with outliers.
} 
an increase of over 30 percent.

\section{[Table 1 here]}

To obtain a single measure of instability, we calculate CHAOS by taking the sum of the number of assassinations, demonstrations, riots, general strikes, and attempted revolutions. While a crude way of aggregating indicators, it has high predictive power. ${ }^{13}$ In the robustness section, we show that alternative methods of reducing data complexity such as principal components analysis do not change our results.

For CHAOS, the average country in our sample registers 1.6 incidents per year. Instability was not constant over time. The maximum is higher - Italy in 1947 saw a total of 38 incidents, including 7 general strikes, 19 riots, and 9 anti-government demonstrations. Figure 2 gives an overview of the evolution over time, plotting the average of CHAOS as well as the maximum number of incidents observed. While there is no clear-cut pattern over time, some features emerge. The interwar period showed relatively high levels of unrest, with an average of 1.8 incidents per year, compared to 1.3 in the post-war period. The immediate post-World War II period, and the period form 1968 to 1994 also show unusually high levels of unrest. Comparatively speaking, the years since 1994 have been unusually tranquil (average CHAOS $=0.68$ ).

\section{[Figure 2 here]}

In compiling information on expenditure and the budget balance data, we need to trade off the accuracy of information against availability over a long time span. We rely on standard data sources on the central government revenue and expenditure relative to GDP from Mitchell (2007), augmented by data from the OECD when available (mostly from 1970 onwards). Expenditure changes will serve as the main explanatory variable. Figure 3 graphs changes in expenditure/GDP from one year to the next. The distribution is almost symmetric around the mean, with similar numbers of countryyears witnessing expenditure increases and declines (787 vs 662). In an average year and country over the period, central government expenditure relative to GDP rose by $0.3 \%$. The vast majority of observations is in the range of changes by less than $3 \%$, with a few outliers in the tails of the distribution (typically driven by the beginning and end of wars).

\section{[Figure 3 here]}

\footnotetext{
${ }^{13}$ One alternative is the weighted conflict index (wci), as compiled by Banks (2010). It gives fixed weights determined to different forms of unrest: Demonstrations have a weight of 200, while political assassinations have a weight of 24 .
} 
When focusing on the sub-period from 1970 to 2007, we use cyclically adjusted fiscal data constructed by Alesina and Ardagna (2010). ${ }^{14}$ In particular we employ their data on primary expenditure, government investment, total revenues and the primary budget balance. In this way we correct for both changes in interest payments and the immediate effect of the economic cycle, which drives both expenditure and revenue without any additional policy decision being taken. For a subsample of the data (1978-2008, 17 countries), we also use data by Devries et al. (2011). These authors examine in detail the policy changes that led to changes in a country's fiscal stance. Only expenditure cuts or revenue increases motivated by a decision to press ahead with fiscal consolidation are considered. ${ }^{15}$ Overall, Devries et al. (2011) find 173 periods of fiscal policy adjustment.

As a first pass at the data, we repeat the exercise in Figure 1 for output growth (Figure 4). We subdivide the sample into terciles, and examine how much the incidence of various indicators of unrest declines as growth accelerates. For the summary indicator (CHAOS), there are a little more than 2 incidents when growth is in the lowest tercile. This falls to 1.3-1.5 incidents as growth accelerates. There is also a clear pattern of decline for demonstrations and for assassinations. In the case of riots, the differences are smaller overall, whereas in the case of general strikes, there seems to be little pattern at all. Based on a first, visual inspection of the data, it seems that the link between budget cuts and unrest is clearer than the one with growth.

\section{[Figure 4 here]}

Next, we examine the correlation structure of our data in Table 2. Assassinations, general strikes, riots, revolutions and demonstrations are all positively and significantly correlated with each other. This supports our assumption that they reflect a broader underlying pattern of social instability and unrest. CHAOS is also positively correlated with the weighted conflict index (wci). Finally, Table 2 suggests that higher levels of expenditure and faster growth are associated with less unrest. The simple correlation of CHAOS with changes in the budget balance is positive and significant. Higher taxes and lower expenditure are associated with more unrest, but the relationship is not significant.

\section{[Table 2 here]}

In the case of output changes, the coefficient is negative, but insignificant (Table 2 ). The simple correlations suggest that these co-movements do not extend to all indicators of unrest equally: riots, revolutions, and demonstrations decline as expenditure

\footnotetext{
${ }^{14}$ Alesina and Ardagna use the method of Blanchard (1990b)

${ }^{15}$ The approach is similar to the "narrative approach" pioneered by Romer and Romer (1989)
} 
rises, but assassinations and strikes seem - at a first pass - uncorrelated. Similarly, output growth seems to correlate negatively with assassinations, riots, revolutions, and demonstrations, but not with strikes. Next, we examine the connection between budget position, expenditure, and unrest more systematically.

\section{Results}

The graphical evidence in Figures 1 and 4 suggests a link between "hard times" - low growth and budget cut-backs - and unrest. Next, we examine if there is a systematic relationship between budget measures and social instability. We present evidence from the last century of budget cuts and turmoil, and then show that these hold if we use a more narrow but cleanly defined measure of austerity. The dynamic nature of responses to spending reductions is also not responsible for our results. Next, we look at interaction effects with institutional factors. Do countries with more accountable governments weather the storms of austerity better? We find an inverse relationship between government spending and unrest at all levels of institutional quality, but the link appears stronger the more authoritarian a regime is. Finally, we examine the impact of media penetration.

\subsection{Baseline Results}

We estimate simple panel regressions of the type:

$$
I_{i t}=\alpha+\alpha_{i}+\alpha_{t}+\beta \Delta B_{i t}+\Gamma X_{i t}^{\prime}+\varepsilon_{i t}
$$

where $I_{i t}$ denotes the level of instability in country $i$ at time $t, \Delta B_{i t}$ is a measure of the change in the budget position, $\alpha_{i}$ is a country-specific intercept, $\alpha_{t}$ is a time-specific dummy, and $X_{i t}$ is a vector of control variables.

We use CHAOS as the dependent variable in our baseline specification, and test the robustness of findings to alternative specifications later. CHAOS is a count variable. To avoid issues of overdispersion, we estimate a negative binomial model clustering standard errors at the country level. ${ }^{16}$ This takes the highly skewed distribution of the number of incidents into account. Table 3 gives the main results. We find that expenditure cuts are strongly and significantly associated with the number of unrest incidents in any one country and year (column 1). The same is true of overall improvements in the budget position (column 3). We find a positive effect of tax rises, but the coefficient is small and the estimated standard error is large (column 2).

\footnotetext{
${ }^{16}$ In the robustness section, we show that Poisson Quasi-Maximum Likelihood estimation yield nearly identical results.
} 
Under OLS with fixed effects and year-dummies, we find the same pattern: expenditure increases reduce instability in a powerful way (column 4). A one standarddeviation cut in expenditure raises the number of incidents (CHAOS) by 0.4 per year and country. Tax increases have a positive sign, but the effect is not significant at standard levels (column 5). It is also small - a one standard deviation rise in the tax/GDP ratio increases unrest by less than 0.01 events. Overall, we find that improvements in the budget balance raise the level of unrest (column 6).

\section{[Table 3 here]}

To illustrate the magnitude of effects, we present the predicted number of incidents per year conditional on different values of expenditure changes and GDP growth. Table 4 performs such an analysis. We see that for any given level of GDP growth, the implied number of unrest episodes rises rapidly as expenditure is cut. At negative growth of $2 \%$, for example, going from expenditure cuts of $1 \%$ to $10 \%$ implies almost a doubling of the frequency of unrest. Compared to this, the effects of poor economic performance are relatively mild. Going from negative growth of $2 \%$ to a collapse by $10 \%$ only increases the predicted number of incidents by 0.18 p.a. [holding expenditure cuts constant at 1\%]. The higher the level of expenditure cuts, the higher the effect of low growth. At expenditure cuts of $10 \%$, the same change in growth rates produces 0.29 extra incidents.

\section{[Table 4 here]}

\subsection{Full Set of Controls, 1970-2007}

The downside of using the full sample, for the years 1919-2008, is that many important covariates are not available. For example, consistent and comparable data on unemployment rates is rare for earlier periods. To address this issue, we estimate the same regressions but with a full set of controls, for a subset of 16 countries over the period 1970-2007.

\section{[Table 5 here]}

We add changes in output per head, unemployment, ethnic fractionalization, polity scores, the debt/GDP level, as well as changes in inflation and the primary budget balance to our set of explanatory variables. For this subset of the sample, our fiscal variables are also more cleanly defined. We can use primary expenditure - net of debt servicing cost - which is conceptually superior. Some of the variation in primary expenditure and total revenue could, however, also reflect changes that are driven by 
automatic stabilizers. To take this into account we cyclically adjust all fiscal variables using the Blanchard methodology (as in Alesina and Ardagna, 2010), in an attempt to clean as much as possible the change in fiscal variables from their cyclical component.

As Table 5 shows, the link between expenditure cuts and unrest remains unaffected, as is the predictive power of the budget position overall. In contrast to the results with the full sample, tax increases appear to be also strongly associated with instability. We will analyze this issue further when using information on the cause of each unrest event. Finally, in column 4, we examine if adjusting the budget position for debt service (using the primary surplus as the explanatory variable) changes our findings; it does not. In addition, we find positive coefficients on ethnic fractionalization and unemployment, which is in line with the results by DiPasquale and Glaeser (1998). Inflation is strongly and negatively associated with unrest, giving credence to theories that see it as a way to preserve "social peace" in economies under pressure (Feldman, 1997).

\subsection{Results with Exogenous Retrenchment Measures}

The obvious challenge in interpreting equation (1) is the potential for omitted variable problems. It is possible that the economic cycle is simultaneously driving both unrest and the need for budget cuts. Above, we already control for GDP growth rates, and our main finding remains unaffected. However, the omitted variable problem would only be solved if we measured the effect of economic output on instability perfectly. Since this is unlikely, we present another type of analysis. We use a recently-developed database on the motivations behind expenditure changes to separate cyclically-driven austerity from deliberately-targeted measures that aim at restoring sustainability over the long run.

In Table 6 we use the IMF measure of policy-action based changes in expenditure, revenues and the budget balance to strengthen the argument for a causal link. Here, the source of variation is identified as cleanly as possible: Only changes in the budget balance motivated by concern about the long-run fiscal position are used. The downside is that we only have information on episodes of fiscal retrenchment (deficit reductions) and not on periods of fiscal expansion. Using this action-based measure as explanatory variables for unrest produces a negative, large and significant coefficient for change in expenditure, a positive and non significant coefficient for change in revenues and a positive and significant coefficient for the budget balance.

In columns 4 to 6 we use the Alesina et al. (2012) decomposition of anticipated and unanticipated changes in fiscal variables to refine the analysis further. For each year, we use the unanticipated share of expenditure, revenues and budget position as 
an additional explanatory variable. As the regression results show, unrest rises the most when spending cuts are unanticipated - rioting and other forms of protest occur in direct response to new policy measures. The closer we get to measuring the impact of policy measures, the stronger the link between austerity and unrest becomes. This strengthens the case for a causal link between unrest and austerity.

\section{[Table 6 here]}

\subsection{Accounting for Dynamics}

So far, we have ignored the time-series dynamics in our data. Unrest shows positive and significant serial correlation for up to 2 years. In addition, we have abstracted from anticipation effects - events on the street may be caused as much by anticipated expenditure cuts, for example, as by those actually taking place. In Table 7, we show results for a number of dynamic specifications. In column 4, we examine the effect of expenditure cuts from $t-2$ (two years previous) to $t+2$. We find that there is a relatively small (and insignificant) effect of expenditure cuts in the previous year. In contrast, the effect of current-year changes remains strong and highly significant. Austerity in the next year also has predictive power for unrest at time $t$ - unrest is just as likely to erupt in response to current as to future austerity. In column 5, we examine the effect of including lagged social instability. While highly significant, the estimated coefficient for the other variables are largely unaffected. The same conclusion emerges from the final column (6); future positive GDP growth is associated with less growth, but the effect is not well-estimated.

\section{[Table 7 here]}

\subsection{Institutions and the Sensitivity of Unrest to Austerity}

Greater constraints on the executive and more democracy should on the one hand reduce social conflict, producing less of a need to take to the streets. ${ }^{17}$ On the other hand, there will be less repression by the authorities in more democratic countries with higher Polity scores, making it easier for protests to be organized. Which effect dominates is not clear ex ante. Table 8 demonstrates that in countries with better institutions, the responsiveness of unrest to budget cuts is generally lower. Where constraints on the executive are minimal, the coefficient on expenditure changes is strongly negative - more spending buys a lot of social peace, and expenditure cuts powerfully fan the flames of discontent. As we limit the sample to ever more democratic

\footnotetext{
${ }^{17}$ For reflections on the relationship between institutions and social conflict, cf. Acemoglu (2003).
} 
countries, the size of the coefficient declines slightly. For mature democracies with a full set of civil rights, the coefficient is still negative, but much smaller and no longer significant. The link with growth is also relatively stable. Higher output generally dents the tendency to riot, demonstrate, assassinate, or strike in countries with low institutional quality. The only exception is in full democracies, where the connection is weaker but still negative, and in the most authoritarian regimes, where there is no clear link.

\section{[Table 8 here]}

\subsection{Media Penetration}

Does greater media penetration increase or reduce unrest? Events in the Arab world in 2010 and early 2011 have led many observers to argue that greater media availability tightens the link between discontent and unrest. Data on media penetration is available in the Banks dataset.Three indicators are relevant - phone penetrations per capita, radio and television take-up. ${ }^{18}$ Radio and television are unidirectional forms of media, allowing typically government-controlled messages to be broadcast to the population. If anything, they should make it easier for authorities to reduce unrest. Phones, on the other hand, allow peer-to-peer communication. All else equal, the expected effect is that they facilitate organized protest. To analyze the data, and to avoid confusing results with the growing availability of broadcasting and telecommunications over time, we rank penetration rate in our sample in each year. We do so separately for each category, and then sum the ranks for each country-year. This gives a rank ordering of media penetration in country $\mathrm{x}$ in year $\mathrm{y}$. We then divide the sample at the median. Table 9, col. (1) and (2) presents the results of estimating standard regressions for these two subsamples. We find that below-average media penetration is associated with a strong effect of expenditure cuts on unrest. Above the median, the effect disappears. In col. (3)-(6), we differentiate between uni-directional information media (info-media) and peer-to-peer telecommunications (peer-media). The attenuation of the effect of expenditure changes is milder for peer-media, and strong for info-media. For both types, the effect of economic conditions is always important above the median for media penetration, but below (in the case of peer media) the effect is small and poorly estimated. These results do not suggest that countries which, at any one point of time, have greater availability of mass media (relative to their neighbors) experience generally higher level of unrest. ${ }^{19}$

\footnotetext{
${ }^{18}$ We disregard data on telegrams since they are unavailable after 1980.

${ }^{19}$ The obvious alternative is to condition on the absolute level of, say, phone penetration. Most of the variation in phone penetration, however, simply reflects GDP growth and the declining cost of telephones relative to all other goods; no clear pattern emerges.
} 
[Table 9 here]

\section{Robustness and Extensions}

In this section, we examine the sensitivity of our results. We test if a more complete set of controls - available for a part of our original sample - can overturn our result, if our main finding holds for sub-periods, and which individual components of unrest are particularly affected by austerity. We also examine if the effect is driven by outliers, whether positive or negative changes in expenditure matter more for the effect on unrest, and whether the effect is constant in all parts of the distribution of the dependent variable. Finally, we test if greater unrest leads to sharper reversals in fiscal policies.

\subsection{Results by Subcomponent of CHAOS}

Which component of CHAOS is most affected by austerity measures? In Table 10 , we use the same specification as in Table 3 using a negative binomial model, looking at the effect of expenditure cuts on each of the components of our aggregate indicator of instability in the full sample: general strikes, demonstrations, riots, and assassinations, and attempted revolutions. Of the five outcome variables, all show the expected sign, and three of them - demonstrations, riots and attempted revolutions - are statistically significant. The variables that do not show a large, significant coefficient are assassinations and general strikes. On average, years with expenditure increases saw fewer general strikes, but there are numerous general strikes that are not an immediate reaction to economic conditions and budget measures (such as, for example, the 1926 general strike in Britain). For the other variables, the coefficients are large, indicating that austerity measures coincide with significant increases in demonstrations, attempted revolutions, riots, and assassinations. In all specifications, the effect of GDP growth on unrest is negative. In contrast to the results for expenditure changes, the effect is not tightly estimated.

\section{[Table 10 here]}

\subsection{Results by Subperiods}

Table 11 takes this analysis one step further, by breaking the period 1919-2008 into four sub-periods. We distinguish the interwar years from the period of post-World War II reconstruction, the period of slowing growth in the 1970s and 1980s, as well as the years after the fall of the Berlin Wall after 1989. For the first two sub-periods, we 
use expenditure relative to GDP as the explanatory variable; thereafter, as a result of greater data availability, it is primary (non-debt) expenditure. In each subperiod, we find the same pattern as in the long-run data. The only exception is the penultimate period, 1970-1989, when the effect of expenditure changes is not as tightly estimated as it is in the other sub-periods. The effect of changes in budget expenditure on unrest is strongest in the period after the fall of the wall, when the estimated coefficient is twice as large as in the earlier periods. The effect of GDP growth is negative except during the post-war boom: More growth was associated with more unrest. While it is difficult to test for the causes of this reversal exactly, it seems plausible that high rates of output growth may have encouraged worker militancy. At a time when many countries reached full employment, this effect seems to have dominated. The normal pattern of GDP growth reducing unrest reasserts itself after 1970. From 1970 onwards, we can control for additional variables, and do so. Inflation seems to have reduced unrest in the 1970s, in line with some of the political economy literature on the origins of high inflation (Samuelson and Solow, 1960). The fall of the Berlin wall saw the spread of Western-style democracy eastwards. The overall connection between austerity and social instability is the same in the expanded sample, and it is highly significant.

\section{[Table 11 here]}

\subsection{Alternative Measure of Unrest}

How much does our main finding depend on the way in which we aggregate unrest? CHAOS is the simple sum of incidents. Instead, we can use the weighted conflict index, as compiled by Banks (2010). It encompasses a larger set of domestic conflicts including, in addition to the components of CHAOS, purges, major government crisis and guerrilla warfare. It also assigns different, fixed weights to each individual component. The correlation coefficient of the variable with CHAOS is 0.75 , significant at the $1 \%$ level. Another alternative is to use the first principal component of the five indicators that go into CHAOS. They all enter with a positive weighting. The first principal component explains 0.42 of the overall variance. The correlation coefficient with CHAOS is 0.98 .

In Table 12, we use both wci and the first principal as dependent variables. Since the dependent variable is no longer a count variable, we use panel OLS, and obtain large and mostly significant coefficients for expenditure changes and the budget position. For the principal component, expenditure increases cut unrest significantly; for the wci, the standard error is slightly above the typical cut-off for significance. As before, there is no clear pattern for tax changes. The results are largely identical in terms of 
magnitude and significance with the baseline results in Table $3 .^{20}$ We conclude that the way in which we measure unrest does not affect our main finding.

\section{[Table 12 here]}

\subsection{Outliers and the Magnitude of Effects in Different Parts of the Distribution}

An additional factor that can be questioned involves the use of a count variable for unrest in the baseline results. The variable CHAOS is designed to capture the intensity of unrest, but it may be that it is influenced by a number of outliers with a high count of incidents. For example, Italy in 1947 saw a decline in expenditure (by $0.6 \%$ ) and also the highest frequency of unrest in our sample, with 38 incidents in a single year. Extreme observations such as this one might make it easier to find significant effects. To examine this potential issue, we transform CHAOS into a simple dichotomous variable, with unrest coded as equal to unity if there are one or more incidents in a country in a single year. In Table 13, we re-estimate the baseline regression with panel logit using country- and year-fixed effects. We find the same results as before - expenditure cuts wreak havoc, tax increases do so only to a small extent and insignificantly. Overall, the budget balance matters for predicting unrest. We conclude that the role of outliers is not decisive in underpinning the relationship we established in baseline results.

\section{[Table 13 here]}

\subsection{Symmetry of Expenditure Increases and Cuts}

Which part of the variation in the explanatory variables is responsible for the link between austerity and unrest? Do increases in expenditure do as much to reduce unrest as cuts increase them? In Table 14, we examine this issue. Column (1) shows the results for expenditure increases. The coefficient is negative, but not large, and not significant. In contrast, if expenditure changes are negative, they matter a great deal for unrest, driving up CHAOS by 0.24 incidents for each standard deviation of expenditure cuts. Next, we repeat the exercise for output changes. Increases in output do much to cut unrest (col. 3), with a one standard deviation increase in output $(3.77 \%)$ reducing CHAOS by 0.2 incidents on average. In contrast, declines do not set off major disruptions to the same degree (but the sample is relatively

\footnotetext{
${ }^{20} \mathrm{~A}$ decrease of 1 GDP point in public expenditure is associated with an increase of 0.04 standard deviations in CHAOS, 0.03 standard-deviations in first principal component of chaos and 0.02 standard-deviations in wci.
} 
small). Overall, the results in table 12 confirm that the relevant identifying variation for expenditure changes comes from cuts; for output changes, it comes from positive growth, not recessions.

\section{[Table 14 here]}

\subsection{Fiscal Reversals}

Does unrest lead to fiscal reversals? Are the politics of the "street" powerful enough to change the minds of politicians implementing austerity programs? Here, we examine the time path of fiscal adjustments, comparing periods of austerity with and without unrest. Figure 5 shows the change in expenditure relative to GDP from year 1 (when the cuts are implemented and unrest either occurs or does not) to year 4 . We compare two groups - countries with austerity programs with and without unrest in year 1. Unsurprisingly given our earlier findings, consolidation episodes associated with unrest on average see more severe budget cuts. In both groups, budget cuts are scaled back after year 1, and spending increases again in year 2. However, the reversal is much more marked during episodes where austerity coincided with unrest. The change in budget position amounts to an almost 3 percentage point swing, from cuts of over 2 percent to increases of more than 0.75 percent. The reversal in countries without unrest is only half as large. In years 3 and 4, expenditure continues to expand in countries that saw unrest, but at a slower pace. In contrast, countries without unrest grow their spending in a more gradual fashion, reaching a higher rate of expansion by year 4. In this sense, our results suggest that austerity programs that are so severe that they fan the flames of unrest can be self-defeating - they lead to a quick reversal of fiscal policy.

\section{[Figure 5 here]}

\section{Conclusions}

We find a close association between unrest and budget cuts in Europe during the period 1919-2008. Because unrest is a low-frequency event, its incidence and association with other factors is best examined in a long-run setting, using data from a large number countries. The link is strong in almost every single sub-periods, and for all types of unrest. ${ }^{21}$ When we use recently-developed data that allows clean

\footnotetext{
${ }^{21}$ Strikingly, where we can trace the cause of each incident (during the period 1980-95), we can show that only austerity-inspired demonstrations respond to budget cuts in the time-series. Cf. Appendix I.
} 
identification of arguably exogenous, policy-driven changes in the budget balance, our results continue to hold. Finally, these findings are not affected by using alternative measures of unrest. Contrary to what might be expected, we find no evidence that the spread of mass media facilitates the rise of mass protests.

The link between fiscal retrenchment and unrest may help to resolve a paradox in the political economy literature. There appears to be no significant punishment at the polls for governments pursuing cut-backs (Alesina et al., 1998; Alesina et al., 2010), and no evidence of gains in response to budget expansion (Brender and Drazen, 2008). Also, the empirical evidence on the economic effects of budget cuts is mixed, with some studies finding an expansionary effect, and others, a contractionary one. ${ }^{22}$ Why, then, is fiscal consolidation often delayed, or only implemented half-heartedly?

Our findings suggest one possible answer why austerity is often avoided - fear of instability and unrest. ${ }^{23}$ Expenditure cuts carry a significant risk of increasing the frequency of riots, anti-government demonstrations, general strikes, political assassinations, and attempts at revolutionary overthrow of the established order. While the type of instability evnts we analyze are infrequent in normal years, they become much more common as tougher austerity measures are implemented. Anticipated properly, they may act as a potent brake on government policy. Once unrest erupts, governments quickly reverse course and increase spending in the following year, according to our results - the politics of the street are effective in reversing austerity. The close link between austerity and instability may also help to explain why countries with higher levels of unrest are on average also more indebted (Woo, 2003).

\footnotetext{
${ }^{22}$ Alesina and Ardagna (2010); Alesina et al. (2002); Guajardo et al. (2011). An early example in the literature is Giavazzi and Pagano (1990)

${ }^{23}$ Alesina et al. (2010) also suggest that implementation of budget measures may be harder if the burden falls disproportionately on some groups. War-of-attrition models of consolidation are one alternative (Alesina and Drazen, 1991).
} 


\section{References}

Acemoglu, D. (2003). "Why not a Political Coase Theorem? Social Conflict, Commitment, and Politics". Journal of Comparative Economics 31(4), 620-652.

Acemoglu, D. and J. Robinson (2000). "Why Did the West Extend the Franchise? Democracy, Inequality, and Growth in Historical Perspective". Quarterly Journal of Economics 115(4), 1167-1199.

Alesina, A. and S. Ardagna (2010). "Large Changes in Fiscal Policy: Taxes versus Spending". Tax Policy and the Economy 24(1), 35-68.

Alesina, A., S. Ardagna, R. Perotti, and F. Schiantarelli (2002). "Fiscal Policy, Profits, and Investment". American Economic Review 92(3), 571-589.

Alesina, A., D. Carloni, and G. Lecce (2010). "The Electoral Consequences of Large Fiscal Adjustments". Harvard University, Mimeo.

Alesina, A. and A. Drazen (1991). "Why Are Stabilizations Delayed?". The American Economic Review 81(5), 1170-1188.

Alesina, A., C. Favero, and F. Giavazzi (2012). "The Output Effect of Fiscal Consolidations". NBER Working Paper No. w18336.

Alesina, A. and R. Perotti (1995). "The Political Economy of Budget Deficits". Staff Papers-International Monetary Fund 42(1), 1-31.

Alesina, A. and R. Perotti (1996). "Political Instability, Income Distribution, and Investment". European Economic Review 40(6), 1203-1228.

Alesina, A., R. Perotti, J. Tavares, M. Obstfeld, and B. Eichengreen (1998). "The Political Economy of Fiscal Adjustments". Brookings Papers on Economic Activity 1998(1), 197-266.

Andronikidou, A. and I. Kovras (2012). "Cultures of Rioting and Anti-Systemic Politics in Southern Europe". West European Politics 35(4), 707-725.

Banks, A. S. (2010). Cross-National Time-Series Data Archive. Databanks International, Jerusalem.

Baxter, M. and R. King (1993). "Fiscal Policy in General Equilibrium". The American Economic Review 83(3), 315-334.

Bertola, G. and A. Drazen (1993). "Trigger Points and Budget Cuts: Explaining the Effects of Fiscal Austerity". The American Economic Review 83(1), 11-26. 
Blanchard, O. (1990a). "Comment on Giavazzi and Pagano, 'Can Severe Fiscal Contractions Be Expansionary?"'. NBER Macroeconomics Annual 5, 111-116.

Blanchard, O. (1990b). "Suggestions for a New Set of Fiscal Indicators". OECD Economics Department Working Papers.

Bloom, N. (2009). "The Impact of Uncertainty Shocks". Econometrica $77(3), 623-685$.

Bohlken, A. and E. Sergenti (2010). "Economic Growth and Ethnic Violence: An Empirical Investigation of Hindu-Muslim Riots in India". Journal of Peace Research $47(5), 589$.

Boix, C. (2003). Democracy and Redistribution. Cambridge University Press, United Kingdom.

Bracher, K. (1978). Die Auflösung der Weimarer Republik. Athenäum-Verlag.

Brender, A. and A. Drazen (2008). "How Do Budget Deficits and Economic Growth Affect Reelection Prospects? Evidence from a Large Panel of Countries". The American Economic Review 98(5), 2203-2220.

Buchanan, J. and G. Tullock (1962). The Calculus of Consent: Logical Foundations of Constitutional Democracy, Volume 100. University of Michigan Press.

Cobban, A. (1964). The Social Interpretation of the French Revolution. Cambridge University Press, United Kingdom.

De Bromhead, A., B. Eichengreen, and K. O'Rourke (2012). "Right-wing Political Extremism in the Great Depression". NBER Working Paper No. w17871.

Devries, P., J. Guajardo, D. Leigh, and A. Pescatori (2011). "A New Action-based Dataset of Fiscal Consolidation". IMF Working Paper No. 11/128.

DiPasquale, D. and E. Glaeser (1998). "The Los Angeles Riot and the Economics of Urban Unrest". Journal of Urban Economics 43(1), 52-78.

Doyle, W. (2001). The French Revolution: a Very Short Introduction, Volume 54. Oxford University Press, USA.

Feldman, G. (1997). The Great Disorder: Politics, Economics, and Society in the German Inflation, 1914-1924. Oxford University Press, USA.

Ferejohn, J. (1986). "Incumbent Performance and Electoral Control". Public Choice 50(1), 5-25. 
Field, E., M. Levinson, R. Pande, and S. Visaria (2008). "Segregation, Rent Control, and Riots: the Economics of Religious Conflict in an Indian City". The American Economic Review 98(2), 505-510.

Francisco, R. (2006). European Protest and Coercion Data.

Giavazzi, F. and M. Pagano (1990). "Can Severe Fiscal Contractions Be Expansionary? Tales of Two Small European Countries". NBER Macroeconomics Annual 1990 5, $75-111$.

Grossman, H. (1991). "A General Equilibrium Model of Insurrections". The American Economic Review 81(4), 912-921.

Guajardo, J., D. Leigh, and A. Pescatori (2011). "Expansionary Austerity: New International Evidence". IMF Working Paper No. 11/158.

Haggard, S., J. Lafay, and C. Morrisson (1995). The Political Feasibility of Adjustment in Developing Countries. OECD.

Hunt, L. (2004). Politics, Culture, and Class in the French Revolution, Volume 1. University of California Press.

IMF (2010). "Will It Hurt? Macroeconomic Effects of Fiscal Consolidation". World Economic Outlook.

Kuran, T. (1989). "Sparks and Prairie Fires: A Theory of Unanticipated Political Revolution". Public Choice 61(1), 41-74.

Maddison, A. (2010). Statistics on World Population, GDP and Per Capita GDP, 1-2008 AD.

Marshall, M. and K. Jaggers (2010). Polity IV Project: Political Regime Characteristics and Transitions, 1800-2010.

Martin, I. and N. Gabay (2012). "Fiscal Protest in Thirteen Welfare States". SocioEconomic Review.

Mitchell, B. (2007). International Historical Statistics: Europe, 1750-2005. Palgrave MacMillan, London.

Morrison, C., L. J.D., and S. Dessus (1994). "Adjustment Programmes and PoliticoEconomic Interactions in Developing Countries: Lessons from an Empirical Analysis of Africa in the 1980s". In From Adjustment to Development in Africa: Conflict, Controversy, Convergence, Consensus? Royal African Society. 
Paldam, M. (1993). The Socio-political Reactions to Balance-of-payments Adjustments in LCDs: A Study of Nine Cases from Latin America. Institute of Economics, Aarhus University.

Patsiurko, N., J. Campbell, and J. Hall (2011). "Measuring Cultural Diversity: Ethnic, Linguistic and Religious Fractionalization in the OECD".

Persson, T., G. Roland, and G. Tabellini (1997). "Separation of Powers and Political Accountability". The Quarterly Journal of Economics 112(4), 1163-1202.

Ramey, V. (2011). "Identifying Government Spending Shocks: It's all in the Timing". The Quarterly Journal of Economics 126(1), 1-50.

Romer, C. and D. Romer (1989). "Does Monetary Policy Matter? A New Test in the Spirit of Friedman and Schwartz". NBER Macroeconomics Annual.

Romer, C. and D. Romer (2010). "The Macroeconomic Effects of Tax Changes: Estimates Based on a New Measure of Fiscal Shocks". The American Economic Review $100(3)$, 763-801.

Rummel, R. and R. Tanter (1971). Dimensions of Conflict Behavior Within and Between Nations, 1955-1960. Number 5021. Inter-University Consortium for Political Research.

Samuelson, P. and R. Solow (1960). "Analytical Aspects of Anti-inflation Policy". The American Economic Review 50(2), 177-194.

Shleifer, A. and R. Vishny (2002). The Grabbing Hand: Government Pathologies and Their Cures. Harvard University Press.

Soboul, A. (1974). The French Revolution, 1787-1799: from the Storming of the Bastille to Napoleon. Random House.

Tullock, G. (1971). "The Paradox of Revolution". Public Choice 11(1), 89-99.

Voth, H. (2011). "Tightening Tensions: Fiscal Policy and Civil Unrest in Eleven South American Countries, 1937-1995”. In J. Galí (Ed.), Fiscal Policy and Macroeconomic Performance. Central Bank of Chile, Santiago de Chile.

Woo, J. (2003). "Economic, Political, and Institutional Determinants of Public Deficits". Journal of Public Economics 87(3-4), 387-426. 


\section{EPCD Dataset and Results (For Online Publication Only)}

The European Protest and Coercion Database (EPCD) developed by Francisco (2006) can be used to pin down the main motive behind each public demonstration. We first describe the dataset and then present results.

\section{European Protest and Coercion Data (1980-1995):}

The EPCD codes daily data on all reported protest events occurred in 28 European countries between 1980 and 1995. The data is constructed using the full-text reports from more than 400 newspapers in the Lexis-Nexis database. We restrict our attention to the same types of protest events covered in the long-term data: riots, demonstrations, political assassinations, general strikes, and attempted revolutions. ${ }^{24}$ The main advantage of the EPCD over the Arthur Banks' database is that the former records the issue behind each protest, allowing us to test the relationship between austerity and unrest in a very precise way, even if only for a small subset of the overall dataset. ${ }^{25}$

There are relatively few protests that are caused by austerity measures. At the same time, when they happen, they involve a large number of participants - by far the largest number of protesters of any category, as Table 15 illustrates. These protests tend to be relatively peaceful, with few protesters arrested, injured or killed, and relatively few members of the security forces involved.

\section{[Table 15 here]}

We define as a single protest event an event recorded with the same entry in the following EPCD variables: event, protester and location. The variable event provides a short description of the main issues of each protest and it is the variable we use to sort protest events into different categories (expenditure cuts, tax increase, economy, peace, labour, education and ecology), protester indicates the protesting group or type (e.g. ferry workers, teachers, truck drivers etc.), location is the geographical location

\footnotetext{
${ }^{24}$ We define as a single protest event an event recorded with the same entry in the following EPCD variables: "event", "protester" and "location". The variable "event" provides a short description of the protest and its reasons, "protester" indicates the protesting group or type (e.g. ferry workers, teachers, truck drivers), "location" is usually the city in which it took place. Events that last more than one day are collapsed in this way in a unique observation, where the number of protesters and security forces members are averages across days. Notice that we only consider protest events whose number of participants is above 100 for riots and demonstrations and above 1000 for general strikes (no threshold is used for assassinations and attempted revolutions). These are the same threshold used in the Banks (2010) database.

${ }^{25}$ For this data we are also able to distinguish among austerity-inspired protests between those whose primary cause is expenditure cuts and those mainly related to tax increases.
} 
in which the event took place. Events that last more than one day are collapsed in this way in a unique observation, where the number of protesters and security forces members are averages across days. Our dependent variable is the number of events in each category occurred in each country-year. Notice that we only consider protest events whose number of participants is above 100 for riots and demonstrations and above 1000 for general strikes (no threshold is used for assassinations and attempted revolutions). These are the same threshold used in the Arthur Banks database.

Data cleaning: We exclude from our estimates one clear outlier, France in 1995, where we register 301 events, against the 2.1 protest events related to expenditure cuts per year that we register on average in Europe. This peak is due to the approval of the Juppé austerity plan that entered into force in 1996.

\section{Results}

We examine if the public assemblies that are motivated by complaints against austerity - as determined by the newspaper records in Lexis-Nexis - are significantly affected by actual changes in fiscal policy. Our approach here is similar to what has been called the "narrative approach" (Romer and Romer (1989)). Table 16 gives the results. If we use the same specification as in Table 3 , we find similar results. Increasing expenditure lowers levels of unrest (column 1). In column 2, we examine the responsiveness of anti-tax demonstrations to revenue increases, and find a weakly positive relationship. The main finding, that anti-austerity protests surge when expenditure is cut, survives controlling for a host of additional variables, including countryand year-fixed effects.

\section{[Table 16 here]}

We can strengthen this result further by conducting a placebo test. In Table 17, we look at other protests, and test if they can be predicted by the same explanatory variables as in Table 16. Labour disputes and demonstrations about the state of the economy are less frequent when expenditure is expanding, but the link is not strong or statistically significant. Peace rallies, ecological issues, and unrest events in response to education policy are actually more frequent in times of fiscal expansion. Overall, the placebo test shows that only in the case of anti-austerity demonstrations is there a strong and significant link with changes in government expenditure.

\section{[Table 17 here]}




\section{Data Appendix (For Online Publication Only)}

\begin{tabular}{ll}
\hline \hline Variable name & Definition \\
\hline $\begin{array}{l}\text { 1. Fiscal variables }(\text { not cyclically adjusted): } \\
\Delta(\exp / \text { GDP })\end{array}$ & $\begin{array}{l}\text { Annual change in total central government spend- } \\
\text { ing as a share of GDP (percentage points) }\end{array}$ \\
$\Delta(\mathrm{rev} / \mathrm{GDP})$ & $\begin{array}{l}\text { Annual change in total central government revenue } \\
\text { as a share of GDP (percentage points) }\end{array}$ \\
$\Delta($ budget/GDP $)$ & $\begin{array}{l}\text { Annual change in total central government budget } \\
\text { as a share of GDP (percentage points) }\end{array}$
\end{tabular}

Source

Time period

Mitchell (2007) from 1919 to

1919-2008

1969; OECD from 1970 to $2008(G T E)$.

Mitchell (2007) from 1919 to 1969; OECD from 1970 to $2008(G T R)$

Mitchell (2007) from 1919

to 1969 ( $\left.\frac{(r e v-e x p)}{G D P}\right)$; OECD from 1970 to 2008 ( (GTE GTR)/B1_GA)

1919-2008

1919-2008

Alesina and Ardagna (2010)

1970-2007

2. Fiscal variables (cyclically adjusted):

$\Delta$ (primary exp/GDP) Annual change in cyclically adjusted current expenditure as a share of GDP (percentage points)

$\Delta($ tot rev/GDP $)$ Annual change in cyclically adjusted total revenue as a share of GDP (percentage points)

$\Delta$ (primary budget/GDP) Annual change in cyclically adjusted primary budget as a share of GDP (percentage points)

3. Fiscal variables (exogenous retrenchment data)

$\Delta(\exp / \mathrm{GDP})^{I M F}$

$\Delta(\mathrm{rev} / \mathrm{GDP})^{I M F}$

$\Delta(\text { budget } / \text { GDP })^{I M F}$

$\Delta(\exp / \mathrm{GDP})_{u}^{I M F}$

$\Delta(\mathrm{rev} / \mathrm{GDP})_{u}^{I M F}$

$\Delta(\text { budget } / \text { GDP })_{u}^{I M F}$

\section{Social unrest variables: CHAOS}

PCA

WCI

General strikes

Demonstrations
Annual change in government expenditure as a share of GDP (percentage points)

Annual change in taxes as a share of GDP (percentage points)

Annual change in government budget as a share of GDP (percentage points)

Unanticipated component of the annual change in government expenditure as a share of GDP (percentage points)

Unanticipated component of the annual change in taxes as a share of GDP (percentage points)

Unanticipated component of the annual change in government budget as a share of GDP (percentage points)

Sum of general trikes, demonstrations, riots, assassinations, revolutions

First principal component of CHAOS

Weighted Conflict Index, weighted sum of: general strikes, demonstrations, riots, assassinations, revolutions, guerrilla warfare, government crises and purges

Any strike of 1,000 or more industrial or service workers that involves more than one employer and that is aimed at national government policies or authority

Any peaceful public gathering of at least 100 people for the primary purpose of displaying or voicing their opposition to government policies or authority (excluding anti-foreign nature demonstrations)
Alesina and Ardagna (2010)

1970-2007

Alesina and Ardagna (2010)

1970-2007

Devries et al. (2011)

$1978-2008$

Devries et al. (2011)

1978-2008

Devries et al. (2011)

1978-2008

Alesina et al. (2012)

1978-2008

Alesina et al. (2012)

1978-2008

Alesina et al. (2012)

1978-2008

Banks (2010)

1919-2008

Banks (2010)

1919-2008

1919-2008

Banks (2010)

1919-2008

Banks (2010)

1919-2008

Banks (2010)

1919-2008 


\begin{tabular}{|c|c|c|c|}
\hline Variable name & Definition & Source & Time period \\
\hline Riots & $\begin{array}{l}\text { Any violent demonstration or clash of more than } \\
100 \text { citizens involving the use of physical force }\end{array}$ & Banks (2010) & $1919-2008$ \\
\hline Assassinations & $\begin{array}{l}\text { Any politically motivated murder or attempted } \\
\text { murder of a high government official or politician }\end{array}$ & Banks (2010) & $1919-2008$ \\
\hline Revolutions & $\begin{array}{l}\text { Any illegal or forced change in the top governmen- } \\
\text { tal elite, any attempt at such a change, or any suc- } \\
\text { cessful or unsuccessful armed rebellion whose aim } \\
\text { is independence from the central government }\end{array}$ & Banks (2010) & $1919-2008$ \\
\hline \multicolumn{4}{|l|}{ 5. Controls: } \\
\hline$\Delta(\mathrm{GDP} / \mathrm{POP})$ & Annual growth in GDP, PPP adjusted & Maddison (2010) & $1919-2008$ \\
\hline Unemployment rate & & OECD Outlook n. 84 & $1970-2007$ \\
\hline Inflation rate & & OECD Outlook n. 84 & $1970-2007$ \\
\hline Primary budget & $\begin{array}{l}\text { Level of cyclically adjusted primary budget as a } \\
\text { share of GDP }\end{array}$ & Alesina and Ardagna (2010) & $1970-2007$ \\
\hline Public debt/GDP & Level of public debt as a share of GDP & OECD Outlook n. 84 & $1970-2007$ \\
\hline Ethnic Fragmentation & $\begin{array}{l}\text { Probability that two randomly selected individu- } \\
\text { als in a country belong to different ethnic groups. } \\
\text { Data is available for } 1985 \text { and } 2000 \text {. We assign the } \\
1985 \text { values to years from } 1970 \text { to } 1990 \text {, and the } \\
2000 \text { value for years from } 1991 \text { to } 2007\end{array}$ & Patsiurko et al. (2011) & 1985,2000 \\
\hline Polity2 & Revised Combined Polity Score & Marshall and Jaggers (2010) & \\
\hline Media & $\begin{array}{l}\text { Sum of the rankings for each country in number of } \\
\text { telephones (including cellular phones) per capita, } \\
\text { radios per capita and televisions per capita }\end{array}$ & $\begin{array}{l}\text { Banks }(2010) \quad(\text { phone6, } \\
\text { media2 and media4) }\end{array}$ & 1919-2008 \\
\hline Info-Media & $\begin{array}{l}\text { Sum of the rankings for each country in number of } \\
\text { telephones (including cellular phones) per capita }\end{array}$ & $\begin{array}{l}\text { Banks }(2010) \quad(\text { phone6, } \\
\text { media2 and media4 })\end{array}$ & $1919-2008$ \\
\hline Peer-Media & $\begin{array}{l}\text { Sum of the rankings for each country in radios per } \\
\text { capita and televisions per capita }\end{array}$ & $\begin{array}{l}\text { Banks } \quad(2010) \quad(\text { phone6, } \\
\text { media2 and media4) }\end{array}$ & 1919-2008 \\
\hline
\end{tabular}

Note on data cleaning of fiscal variables: To take deal with outliers we use as a general rule to drop all observations for which the change in the budget position with respect to the previous year is larger than $10 \%$ in absolute value. This procedure excludes 17 observations from the sample: Belgium in 1948 and 1949, Czech Republic in 1921, 1924 and 1996, United Kingdom in 1946 and 1947, Greece in 1930 and 1931, Ireland in 1965, Italy in 1920, 1923, 1936 and 1937, Netherlands in 1946 and 1948, Yugoslavia in1932. 


\section{Figures}

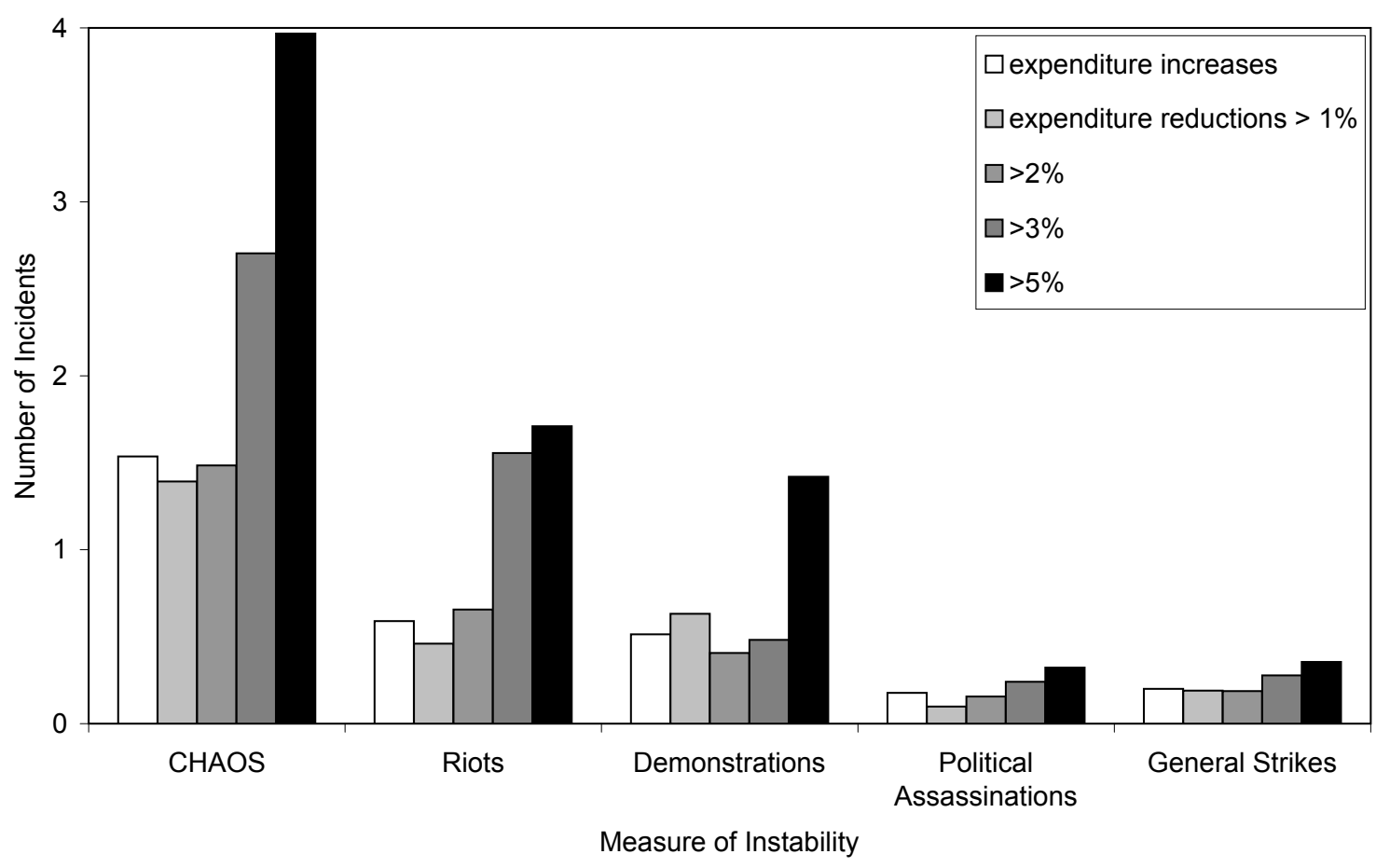

Figure 1: Frequency of Incidents and the Scale of Expenditure Cuts

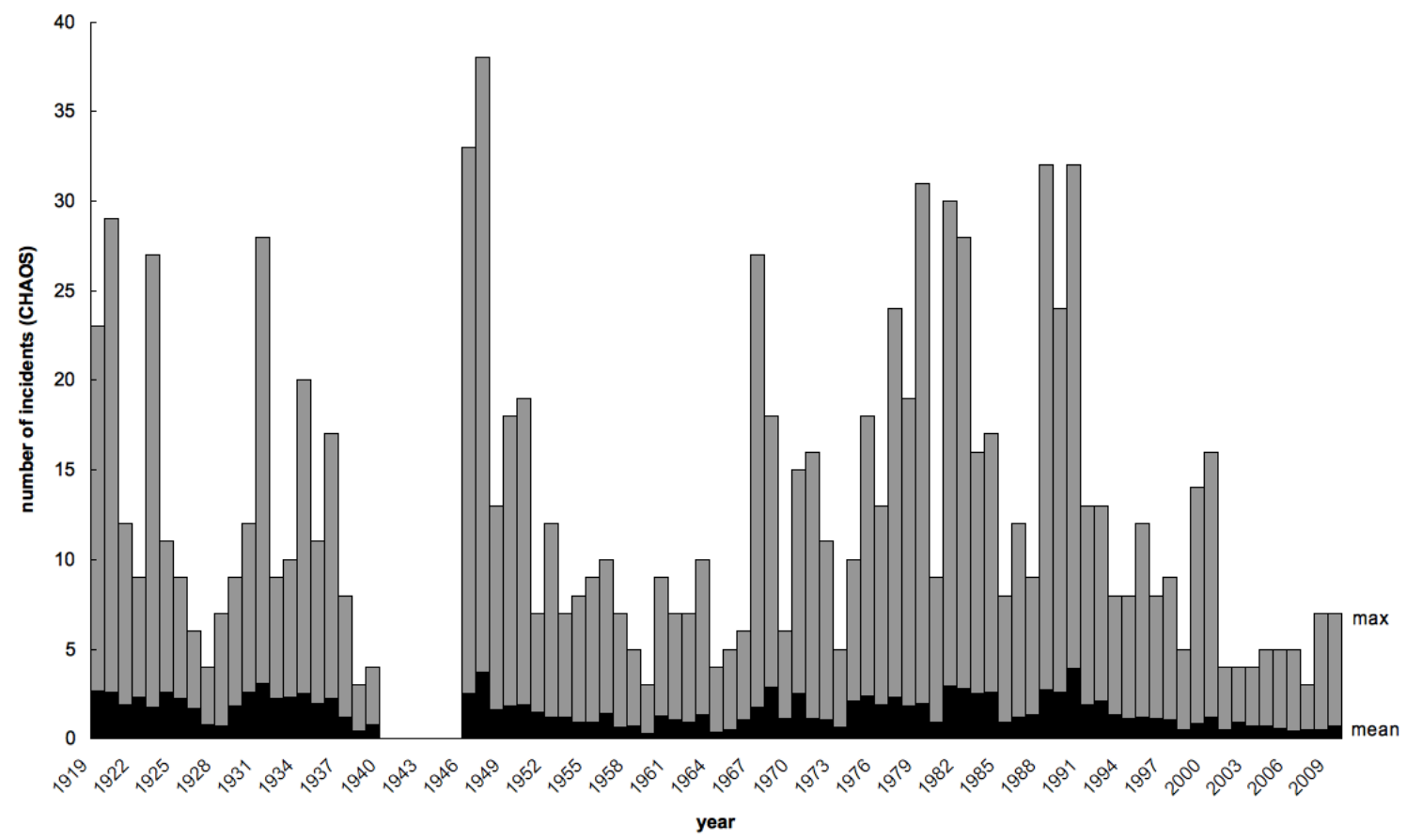

Figure 2: CHAOS over Time 

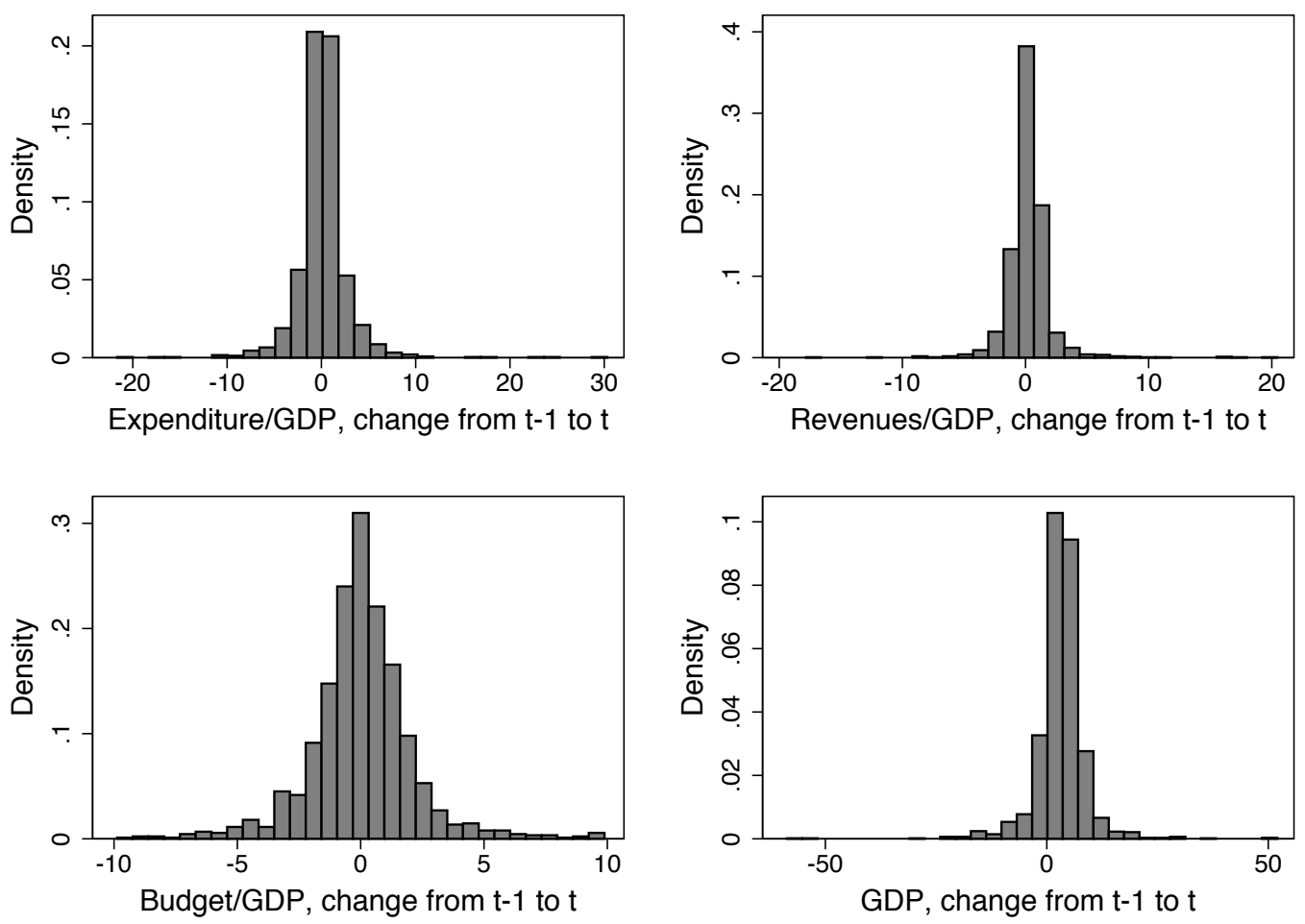

Figure 3: Changes in Fiscal Variables and GDP Per Capita (\% points)

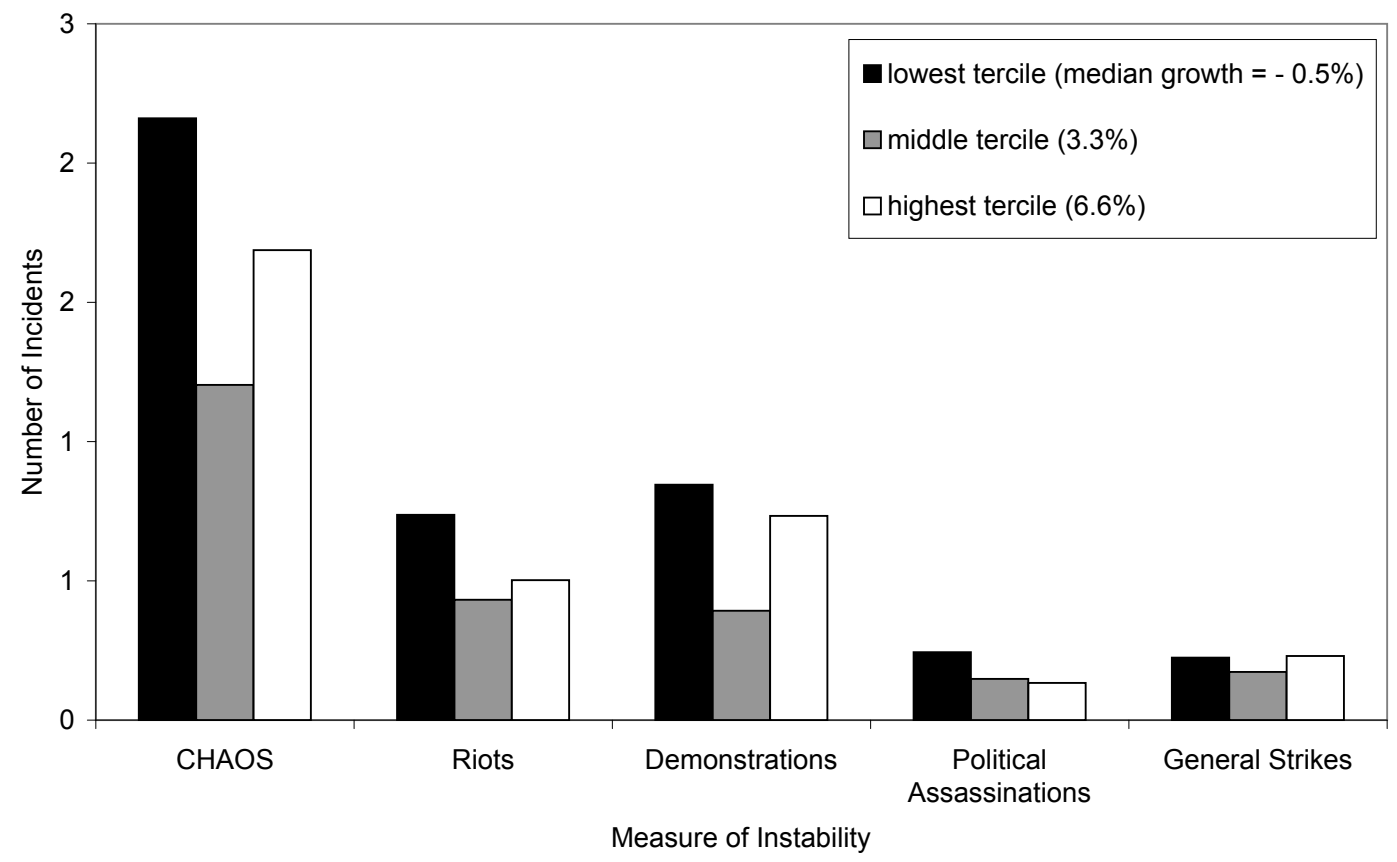

Figure 4: Frequency of Incidents and Economic Growth 


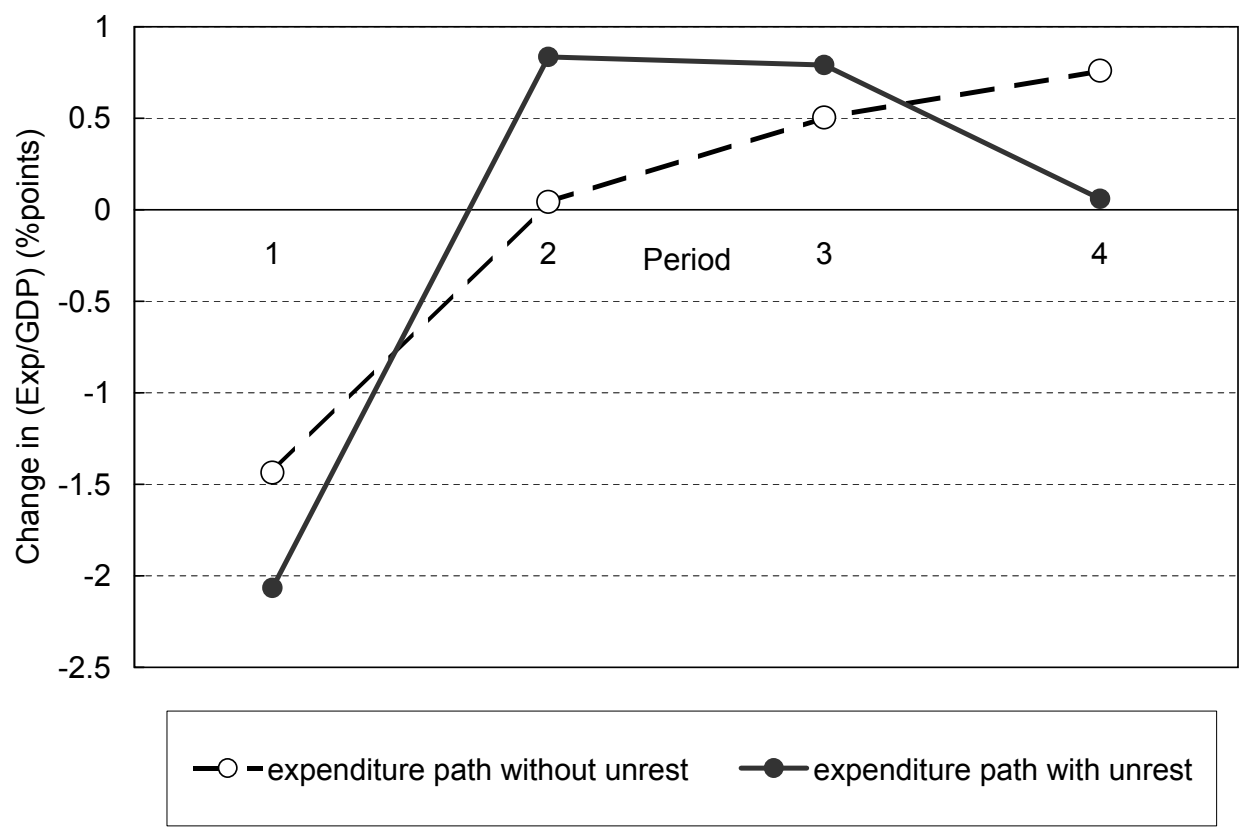

Figure 5: Average Change in Expenditure/GDP in Years After Expenditure Cuts

\section{Tables}

Table 1: Descriptive Statistics

\begin{tabular}{lrrrrr}
\hline \hline & Mean & Std. Dev. & Min. & Max. & Observations \\
\hline$\Delta$ (exp/GDP) & 0.2 & 2.8 & -21.7 & 30.3 & 1449 \\
$\Delta$ (rev/GDP) & 0.2 & 1.9 & -17.8 & 20.5 & 1398 \\
$\Delta$ (budget/GDP) & 0.0 & 2.2 & -9.9 & 9.9 & 1392 \\
$\Delta$ (GDP) & 3.2 & 5.7 & -58.7 & 52.1 & 1788 \\
CHAOS & 1.636 & 3.753 & 0 & 38 & 1797 \\
Riots & 0.635 & 1.997 & 0 & 25 & 1797 \\
Demonstrations & 0.535 & 1.53 & 0 & 17 & 1797 \\
Political Assassinations & 0.177 & 0.762 & 0 & 15 & 1797 \\
General Strikes & 0.196 & 0.654 & 0 & 7 & 1797 \\
Revolutions & 0.093 & 0.361 & 0 & 5 & 1797 \\
\hline
\end{tabular}

Notes: Fiscal variables and GDP growth expressed in $\%$ points. 
Table 2: Cross-correlation Table

\begin{tabular}{|c|c|c|c|c|c|c|c|c|c|c|}
\hline & $\Delta\left(\frac{e x p}{G D P}\right)$ & $\left(\frac{r e v}{G D P}\right)$ & $\left(\frac{\text { budget }}{G D P}\right)$ & $\Delta(\mathrm{GDP})$ & CHAOS & Riots & Demonstr. & $\begin{array}{l}\text { Political } \\
\text { Assassin. }\end{array}$ & $\begin{array}{c}\text { General } \\
\text { Strikes }\end{array}$ & Revolutions \\
\hline$\Delta(\exp /$ GDP $)$ & 1.000 & & & & & & & & & \\
\hline$\Delta(\mathrm{rev} / \mathrm{GDP})$ & $\begin{array}{c}0.627 \\
(0.000)\end{array}$ & 1.000 & & & & & & & & \\
\hline$\Delta$ (budget/GDP) & $\begin{array}{l}-0.711 \\
(0.000)\end{array}$ & $\begin{array}{c}0.102 \\
(0.000)\end{array}$ & 1.000 & & & & & & & \\
\hline$\Delta(\mathrm{GDP})$ & $\begin{array}{l}-0.151 \\
(0.000)\end{array}$ & $\begin{array}{l}-0.036 \\
(0.195)\end{array}$ & $\begin{array}{c}0.200 \\
(0.000)\end{array}$ & 1.000 & & & & & & \\
\hline CHAOS & $\begin{array}{l}-0.062 \\
(0.021)\end{array}$ & $\begin{array}{c}0.036 \\
(0.193)\end{array}$ & $\begin{array}{c}0.065 \\
(0.017)\end{array}$ & $\begin{array}{l}-0.079 \\
(0.001)\end{array}$ & 1.000 & & & & & \\
\hline Riots & $\begin{array}{l}-0.065 \\
(0.016)\end{array}$ & $\begin{array}{c}0.027 \\
(0.317)\end{array}$ & $\begin{array}{c}0.079 \\
(0.004)\end{array}$ & $\begin{array}{l}-0.030 \\
(0.224)\end{array}$ & $\begin{array}{c}0.867 \\
(0.000)\end{array}$ & 1.000 & & & & \\
\hline Demonstrations & $\begin{array}{l}-0.052 \\
(0.054)\end{array}$ & $\begin{array}{c}0.032 \\
(0.239)\end{array}$ & $\begin{array}{c}0.020 \\
(0.466)\end{array}$ & $\begin{array}{l}-0.098 \\
(0.000)\end{array}$ & $\begin{array}{c}0.763 \\
(0.000)\end{array}$ & $\begin{array}{c}0.464 \\
(0.000)\end{array}$ & 1.000 & & & \\
\hline Political Assassinations & $\begin{array}{c}0.006 \\
(0.816)\end{array}$ & $\begin{array}{c}0.015 \\
(0.583)\end{array}$ & $\begin{array}{c}0.006 \\
(0.835)\end{array}$ & $\begin{array}{c}-0.064 \\
(0.010)\end{array}$ & $\begin{array}{c}0.439 \\
(0.000)\end{array}$ & $\begin{array}{c}0.213 \\
(0.000)\end{array}$ & $\begin{array}{c}0.188 \\
(0.000)\end{array}$ & 1.000 & & \\
\hline General Strikes & $\begin{array}{l}-0.030 \\
(0.259)\end{array}$ & $\begin{array}{c}0.039 \\
(0.150)\end{array}$ & $\begin{array}{c}0.060 \\
(0.028)\end{array}$ & $\begin{array}{l}-0.009 \\
(0.718)\end{array}$ & $\begin{array}{c}0.599 \\
(0.000)\end{array}$ & $\begin{array}{c}0.447 \\
(0.000)\end{array}$ & $\begin{array}{c}0.344 \\
(0.000)\end{array}$ & $\begin{array}{c}0.147 \\
(0.000)\end{array}$ & 1.000 & \\
\hline Revolutions & $\begin{array}{l}-0.027 \\
(0.311)\end{array}$ & $\begin{array}{l}-0.025 \\
(0.371)\end{array}$ & $\begin{array}{c}0.029 \\
(0.284)\end{array}$ & $\begin{array}{l}-0.091 \\
(0.000)\end{array}$ & $\begin{array}{c}0.354 \\
(0.000)\end{array}$ & $\begin{array}{c}0.259 \\
(0.000)\end{array}$ & $\begin{array}{c}0.111 \\
(0.000)\end{array}$ & $\begin{array}{c}0.220 \\
(0.000)\end{array}$ & $\begin{array}{c}0.175 \\
(0.000)\end{array}$ & 1.000 \\
\hline
\end{tabular}


Table 3: Baseline Result

\begin{tabular}{|c|c|c|c|c|c|c|}
\hline \multirow[t]{2}{*}{$\begin{array}{l}\text { Dependent variable: CHAOS } \\
\text { Estimator: }\end{array}$} & \multicolumn{3}{|c|}{ Negative Binomial } & \multicolumn{3}{|c|}{ OLS } \\
\hline & $(1)$ & $(2)$ & $(3)$ & $(4)$ & $(5)$ & $(6)$ \\
\hline$\Delta(\exp / \mathrm{GDP})$ & $\begin{array}{c}-0.049 * * \\
{[0.022]}\end{array}$ & & & $\begin{array}{r}-0.146^{* *} \\
{[0.057]}\end{array}$ & & \\
\hline$\Delta(\mathrm{rev} / \mathrm{GDP})$ & & $\begin{array}{c}0.003 \\
{[0.020]}\end{array}$ & & & $\begin{array}{l}-0.003 \\
{[0.048]}\end{array}$ & \\
\hline$\Delta($ budget/GDP $)$ & & & $\begin{array}{c}0.075^{* * *} \\
{[0.027]}\end{array}$ & & $0.131^{*}$ & {$[0.065]$} \\
\hline$\Delta(\mathrm{GDP})$ & $\begin{array}{c}-0.030^{* *} \\
{[0.012]}\end{array}$ & $\begin{array}{r}-0.025^{*} \\
{[0.013]}\end{array}$ & $\begin{array}{c}-0.030^{* *} \\
{[0.013]}\end{array}$ & $\begin{array}{l}-0.006 \\
{[0.070]}\end{array}$ & $\begin{array}{c}0.019 \\
{[0.082]}\end{array}$ & $\begin{array}{r}0.007 \\
{[0.083]}\end{array}$ \\
\hline $\begin{array}{l}\text { Observations } \\
\text { R-squared }\end{array}$ & 1,310 & 1,259 & 1,253 & $\begin{array}{l}1,310 \\
0.119\end{array}$ & $\begin{array}{l}1,259 \\
0.108\end{array}$ & $\begin{array}{l}1,253 \\
0.114\end{array}$ \\
\hline Number of countries & 24 & 24 & 24 & 24 & 24 & 24 \\
\hline
\end{tabular}

Notes: Standard errors clustered at country level in parentheses. Significance levels:*** $\mathrm{p}<0.01,{ }^{* *} \mathrm{p}<0.05$, $* \mathrm{p}<0.1$. All regressions include country and year fixed effects.

Table 4: Predicted Number of CHAOS Episodes Under Different Expenditure Reductions and GDP Growth

\begin{tabular}{rrrrrrr}
\hline \hline & \multicolumn{5}{c}{ GDP Growth } \\
& $3 \%$ & $-2 \%$ & $-5 \%$ & $-10 \%$ \\
\hline \multirow{2}{*}{ Expenditure Reduction $=1 \%$} & 0.58 & 0.69 & 0.75 & 0.87 \\
& $5 \%$ & 0.71 & 0.84 & 0.92 & 1.06 \\
& $10 \%$ & 0.91 & 1.07 & 1.17 & 1.36 \\
& $15 \%$ & 1.16 & 1.37 & 1.50 & 1.74
\end{tabular}


Table 5: Full Set of Controls, 1970-2007

\begin{tabular}{|c|c|c|c|c|c|c|}
\hline $\begin{array}{l}\text { Dependent variable: CHAOS } \\
\text { Estimator: Negative Binomial }\end{array}$ & $(1)$ & $(2)$ & $(3)$ & $(4)$ & $(5)$ & $(6)$ \\
\hline$\Delta($ primary $\exp /$ GDP $)$ & $\begin{array}{c}-0.128^{* *} \\
{[0.057]}\end{array}$ & $\begin{array}{c}-0.204^{* *} \\
{[0.104]}\end{array}$ & & & & \\
\hline$\Delta($ tot rev/GDP $)$ & & & $\begin{array}{l}0.095^{*} \\
{[0.055]}\end{array}$ & $\begin{array}{c}0.165^{* * *} \\
{[0.042]}\end{array}$ & & \\
\hline$\Delta$ (primary budget/GDP $)$ & & & & & $\begin{array}{l}0.074^{*} \\
{[0.040]}\end{array}$ & $\begin{array}{c}0.129 * * \\
{[0.055]}\end{array}$ \\
\hline$\Delta(\mathrm{GDP})$ & $\begin{array}{c}-0.133^{* * *} \\
{[0.044]}\end{array}$ & $\begin{array}{c}-0.247^{* *} \\
{[0.112]}\end{array}$ & $\begin{array}{c}-0.088^{* *} \\
{[0.044]}\end{array}$ & $\begin{array}{l}-0.136 \\
{[0.112]}\end{array}$ & $\begin{array}{c}-0.111^{* * *} \\
{[0.041]}\end{array}$ & $\begin{array}{c}-0.193^{*} \\
{[0.099]}\end{array}$ \\
\hline Lag unemployment rate & & $\begin{array}{c}0.039 \\
{[0.075]}\end{array}$ & & $\begin{array}{c}0.054 \\
{[0.079]}\end{array}$ & & $\begin{array}{c}0.043 \\
{[0.080]}\end{array}$ \\
\hline Ethnic fragmentation & & $\begin{array}{c}3.909 * * * \\
{[0.832]}\end{array}$ & & $\begin{array}{c}3.722^{* * *} \\
{[0.847]}\end{array}$ & & $\begin{array}{c}4.063 * * * \\
{[0.813]}\end{array}$ \\
\hline Polity2 index & & $\begin{array}{c}0.239 \\
{[0.352]}\end{array}$ & & $\begin{array}{c}0.223 \\
{[0.325]}\end{array}$ & & $\begin{array}{c}0.203 \\
{[0.342]}\end{array}$ \\
\hline Log (POP) & & $\begin{array}{c}4.274 \\
{[6.308]}\end{array}$ & & $\begin{array}{c}3.958 \\
{[5.536]}\end{array}$ & & $\begin{array}{c}3.010 \\
{[5.733]}\end{array}$ \\
\hline Public debt/GDP & & $\begin{array}{c}-0.642 \\
{[1.109]}\end{array}$ & & $\begin{array}{l}-0.380 \\
{[1.173]}\end{array}$ & & $\begin{array}{l}-0.560 \\
{[1.170]}\end{array}$ \\
\hline$\Delta$ inflation & & $\begin{array}{c}-0.058^{* *} \\
{[0.027]}\end{array}$ & & $\begin{array}{l}-0.050 \\
{[0.034]}\end{array}$ & & $\begin{array}{c}-0.062^{* *} \\
{[0.030]}\end{array}$ \\
\hline Primary budget & & $\begin{array}{l}-0.034 \\
{[0.055]}\end{array}$ & & $\begin{array}{l}-0.044 \\
{[0.050]}\end{array}$ & & $\begin{array}{l}-0.063 \\
{[0.058]}\end{array}$ \\
\hline Observations & 522 & 434 & 522 & 434 & 522 & 434 \\
\hline Number of countries & 16 & 16 & 16 & 16 & 16 & 16 \\
\hline
\end{tabular}

Notes: Standard errors clustered at country level in parentheses. Significance levels: ${ }^{* *} \mathrm{p}<0.01,{ }^{* *} \mathrm{p}<0.05,{ }^{*} \mathrm{p}<0.1$. All regressions include country and year fixed effects. All fiscal data are cyclically adjusted using the Blanchard methodology. 
Table 6: Exogenous Fiscal Adjustment

\begin{tabular}{|c|c|c|c|c|c|c|}
\hline $\begin{array}{l}\text { Dependent variable: CHAOS } \\
\text { Estimator: Negative Binomial }\end{array}$ & $(1)$ & $(2)$ & $(3)$ & $(4)$ & $(5)$ & $(6)$ \\
\hline$\Delta(\exp / \mathrm{GDP})^{I M F}$ & $\begin{array}{c}-0.805^{* * *} \\
{[0.199]}\end{array}$ & & & & & \\
\hline$\Delta(\exp / \mathrm{GDP}){ }_{u}^{I M F}$ & & & & $\begin{array}{c}-0.920^{* * *} \\
{[0.236]}\end{array}$ & & \\
\hline$\Delta(\mathrm{rev} / \mathrm{GDP})^{I M F}$ & & $\begin{array}{l}-0.038 \\
{[0.245]}\end{array}$ & & & & \\
\hline$\Delta(\mathrm{rev} / \mathrm{GDP}){ }_{u}^{I M F}$ & & & & & $\begin{array}{c}0.280 \\
{[0.248]}\end{array}$ & \\
\hline$\Delta$ (budget/GDP) ${ }^{I M F}$ & & & $\begin{array}{c}0.296^{* *} \\
{[0.123]}\end{array}$ & & & \\
\hline$\Delta$ (budget/GDP) ${ }_{u}^{I M F}$ & & & & & & $\begin{array}{c}0.414^{* * *} \\
{[0.119]}\end{array}$ \\
\hline$\Delta(\mathrm{GDP})$ & $\begin{array}{c}-0.760 * * \\
{[0.362]}\end{array}$ & $\begin{array}{c}-0.738^{*} \\
{[0.383]}\end{array}$ & $\begin{array}{c}-0.767^{* *} \\
{[0.373]}\end{array}$ & $\begin{array}{c}-0.758^{* *} \\
{[0.334]}\end{array}$ & $\begin{array}{c}-0.690^{* *} \\
{[0.333]}\end{array}$ & $\begin{array}{c}-0.736^{* *} \\
{[0.344]}\end{array}$ \\
\hline Lag unemployment rate & $\begin{array}{l}0.211^{*} \\
{[0.116]}\end{array}$ & $\begin{array}{c}0.298^{* *} \\
{[0.135]}\end{array}$ & $\begin{array}{c}0.313^{* * *} \\
{[0.103]}\end{array}$ & $\begin{array}{l}0.204^{*} \\
{[0.120]}\end{array}$ & $\begin{array}{c}0.333^{* * *} \\
{[0.111]}\end{array}$ & $\begin{array}{c}0.281^{* * *} * \\
{[0.100]}\end{array}$ \\
\hline Ethnic fragmentation & $\begin{array}{c}8.348^{* *} \\
{[3.735]}\end{array}$ & $\begin{array}{l}7.019^{*} \\
{[4.020]}\end{array}$ & $\begin{array}{l}7.121^{*} \\
{[4.000]}\end{array}$ & $\begin{array}{c}7.896^{* *} \\
{[3.338]}\end{array}$ & $\begin{array}{c}8.910^{* *} \\
{[3.664]}\end{array}$ & $\begin{array}{l}6.917^{*} \\
{[3.681]}\end{array}$ \\
\hline Polity2 index & $\begin{array}{c}1.693 \\
{[2.390]}\end{array}$ & $\begin{array}{l}1.529 \\
{[2.375]}\end{array}$ & $\begin{array}{c}2.082 \\
{[2.506]}\end{array}$ & $\begin{array}{c}1.744 \\
{[2.161]}\end{array}$ & $\begin{array}{c}1.832 \\
{[2.279]}\end{array}$ & $\begin{array}{c}2.376 \\
{[2.394]}\end{array}$ \\
\hline $\log (\mathrm{POP})$ & $\begin{array}{c}8.980 \\
{[29.190]}\end{array}$ & $\begin{array}{c}13.367 \\
{[27.430]}\end{array}$ & $\begin{array}{c}11.933 \\
{[30.662]}\end{array}$ & $\begin{array}{c}12.277 \\
{[29.229]}\end{array}$ & $\begin{array}{c}6.039 \\
{[25.179]}\end{array}$ & $\begin{array}{c}11.255 \\
{[30.940]}\end{array}$ \\
\hline Public debt/GDP & $\begin{array}{l}-10.191^{* * *} \\
{[1.650]}\end{array}$ & $\begin{array}{c}-9.551 * * * \\
{[1.801]}\end{array}$ & $\begin{array}{c}-10.337^{* * *} \\
{[1.782]}\end{array}$ & $\begin{array}{c}-10.437 * * * \\
{[1.895]}\end{array}$ & $\begin{array}{c}-9.950 * * * \\
{[2.031]}\end{array}$ & $\begin{array}{l}-10.274^{* * *} \\
{[2.005]}\end{array}$ \\
\hline$\Delta$ inflation & $\begin{array}{c}-0.379^{* *} \\
{[0.156]}\end{array}$ & $\begin{array}{c}-0.287^{*} \\
{[0.166]}\end{array}$ & $\begin{array}{c}-0.298^{*} \\
{[0.164]}\end{array}$ & $\begin{array}{c}-0.444^{* * *} \\
{[0.150]}\end{array}$ & $\begin{array}{c}-0.271^{*} \\
{[0.138]}\end{array}$ & $\begin{array}{c}-0.334^{* *} \\
{[0.152]}\end{array}$ \\
\hline Primary budget & $\begin{array}{c}0.091 \\
{[0.081]}\end{array}$ & $\begin{array}{c}0.094 \\
{[0.073]}\end{array}$ & $\begin{array}{l}0.120^{*} \\
{[0.071]}\end{array}$ & $\begin{array}{c}0.083 \\
{[0.089]}\end{array}$ & & $\begin{array}{c}0.119 \\
{[0.079]}\end{array}$ \\
\hline Observations & 105 & 105 & 105 & 105 & 105 & 105 \\
\hline Number of countries & 12 & 12 & 12 & 12 & 12 & 12 \\
\hline
\end{tabular}

Notes: Standard errors clustered at country level in parentheses. Significance levels:** $\mathrm{p}<0.01,{ }^{* *} \mathrm{p}<0.05,{ }^{*} \mathrm{p}<0.1$. All regressions include country and year fixed effects. 
Table 7: Accounting for Dynamics

\begin{tabular}{|c|c|c|c|}
\hline $\begin{array}{l}\text { Dependent variable: CHAOS } \\
\text { Estimator: Negative Binomial }\end{array}$ & (1) & $(2)$ & $(3)$ \\
\hline$\Delta(\exp / \mathrm{GDP})_{t-2}$ & $\begin{array}{c}0.012 \\
{[1.655]}\end{array}$ & $\begin{array}{c}1.668 \\
{[1.694]}\end{array}$ & $\begin{array}{c}1.726 \\
{[1.700]}\end{array}$ \\
\hline$\Delta(\exp / \mathrm{GDP})_{t-1}$ & $\begin{array}{l}-1.943 \\
{[1.761]}\end{array}$ & $\begin{array}{l}-1.206 \\
{[1.279]}\end{array}$ & $\begin{array}{l}-1.318 \\
{[1.289]}\end{array}$ \\
\hline$\Delta(\exp / \mathrm{GDP})_{t}$ & $\begin{array}{c}-0.050 * * \\
{[0.020]}\end{array}$ & $\begin{array}{c}-0.043^{*} \\
{[0.024]}\end{array}$ & $\begin{array}{c}-0.044^{*} \\
{[0.024]}\end{array}$ \\
\hline$\Delta(\exp / \mathrm{GDP})_{t+1}$ & $\begin{array}{c}-5.097^{* *} \\
{[2.254]}\end{array}$ & $\begin{array}{c}-5.148 * * * \\
{[1.917]}\end{array}$ & $\begin{array}{c}-5.288 * * * \\
{[2.013]}\end{array}$ \\
\hline$\Delta(\exp / \mathrm{GDP})_{t+2}$ & $\begin{array}{l}-0.956 \\
{[2.196]}\end{array}$ & $\begin{array}{l}-1.233 \\
{[1.864]}\end{array}$ & $\begin{array}{l}-1.280 \\
{[1.777]}\end{array}$ \\
\hline $\mathrm{CHAOS}_{t-1}$ & & $\begin{array}{c}0.083^{* * *} \\
{[0.009]}\end{array}$ & $\begin{array}{c}0.084^{* * * *} \\
{[0.009]}\end{array}$ \\
\hline$\Delta(\mathrm{GDP}) t$ & $\begin{array}{l}-0.014 \\
{[0.018]}\end{array}$ & $\begin{array}{l}-0.026 \\
{[0.017]}\end{array}$ & $\begin{array}{l}-0.026 \\
{[0.017]}\end{array}$ \\
\hline$\Delta(\mathrm{GDP})_{t+1}$ & & & $\begin{array}{l}-2.070 \\
{[2.029]}\end{array}$ \\
\hline Observations & 1,199 & 1,193 & 1,193 \\
\hline Number of countries & 23 & 23 & 23 \\
\hline
\end{tabular}

Table 8: Institutions and the Sensitivity of Unrest to Austerity

\begin{tabular}{lcccc}
\hline \hline & \multicolumn{4}{c}{ Polity2 Index } \\
Dependent variable: CHAOS & $<-6$ & $<5$ & $<10$ & $=10$ \\
Estimator: Negative Binomial & $(1)$ & $(2)$ & $(3)$ & $(4)$ \\
\hline & & & & \\
$\Delta(\exp / \mathrm{GDP})$ & $-0.117^{* *}$ & $-0.109^{* * *}$ & $-0.095^{* * *}$ & -0.033 \\
$\Delta(\mathrm{GDP})$ & {$[0.054]$} & {$[0.029]$} & {$[0.022]$} & {$[0.023]$} \\
& 0.003 & -0.004 & -0.029 & -0.016 \\
& {$[0.034]$} & {$[0.027]$} & {$[0.026]$} & {$[0.039]$} \\
Observations & 149 & 248 & 383 & 915 \\
Number of countries & 8 & 11 & 17 & 19 \\
\hline
\end{tabular}

Notes: Standard errors clustered at country level in parentheses. Significance levels:*** $\mathrm{p}<0.01,{ }^{* *} \mathrm{p}<0.05,{ }^{*} \mathrm{p}<0.1$. All regressions include country and year fixed effects. 
Table 9: Media Penetration and Unrest

\begin{tabular}{lcccccc}
\hline \hline & \multicolumn{2}{c}{ Media } & \multicolumn{2}{c}{ Info-Media } & \multicolumn{2}{c}{ Peer-Media } \\
Dependent variable: CHAOS & $<$ median & $>$ median & $<$ median & $>$ median & $<$ median & $>$ median \\
Estimator: Negative Binomial & $(1)$ & $(2)$ & $(3)$ & $(4)$ & $(5)$ & $(6)$ \\
\hline \multirow{2}{*}{ (exp/GDP) } & & & & & & \\
& $-0.067^{* * *}$ & 0.019 & $-0.077^{* * *}$ & 0.011 & $-0.071^{* * *}$ & $-0.050^{*}$ \\
$\Delta(\mathrm{GDP})$ & {$[0.024]$} & {$[0.037]$} & {$[0.027]$} & {$[0.034]$} & {$[0.024]$} & {$[0.027]$} \\
& $-0.074^{*}$ & -0.084 & $-0.085^{* *}$ & -0.091 & $-0.035^{*}$ & $-0.062^{* * *}$ \\
& {$[0.040]$} & {$[0.072]$} & {$[0.042]$} & {$[0.073]$} & {$[0.020]$} & {$[0.019]$} \\
Observations & 281 & 499 & 306 & 474 & 510 & 800 \\
Number of countries & 16 & 19 & 15 & 17 & 18 & 18 \\
\hline
\end{tabular}

Notes: Standard errors clustered at country level reported in parentheses. Significance levels: ${ }^{* * *} \mathrm{p}<0.01, * * \mathrm{p}<0.05$, * $\mathrm{p}<0.1$. Media includes phones, radio and TV. Infor-Media includes radio and TV. Peer-Media includes phones. All regressions include country and year fixed effects.

Table 10: Results by Subcomponent of CHAOS

\begin{tabular}{|c|c|c|c|c|}
\hline \multirow[b]{2}{*}{$\begin{array}{l}\text { Dependent variable } \\
\text { indicated in columns } \\
\text { Estimator: Negative Binomial }\end{array}$} & \multicolumn{4}{|c|}{ Subcomponents } \\
\hline & $\begin{array}{l}\text { Riots } \\
(1) \\
\end{array}$ & $\begin{array}{l}\text { Demonstrations } \\
\qquad(2) \\
\end{array}$ & $\begin{array}{c}\text { Political } \\
\text { Assassinations } \\
(3) \\
\end{array}$ & $\begin{array}{l}\text { General } \\
\text { Strikes } \\
(4)\end{array}$ \\
\hline$\Delta(\exp / \mathrm{GDP})$ & $\begin{array}{c}-0.040^{*} \\
{[0.021]}\end{array}$ & $\begin{array}{c}-0.041^{*} \\
{[0.022]}\end{array}$ & $\begin{array}{c}-0.059^{* * *} \\
{[0.021]}\end{array}$ & $\begin{array}{l}-0.045 \\
{[0.031]}\end{array}$ \\
\hline$\Delta(\mathrm{GDP})$ & $\begin{array}{l}-0.013 \\
{[0.014]}\end{array}$ & $\begin{array}{l}-0.034 \\
{[0.022]}\end{array}$ & $\begin{array}{l}-0.019 \\
{[0.021]}\end{array}$ & $\begin{array}{l}-0.002 \\
{[0.027]}\end{array}$ \\
\hline Observations & 1,310 & 1,310 & 1,310 & 1,310 \\
\hline Number of countries & 24 & 24 & 24 & 24 \\
\hline
\end{tabular}

Notes: Standard errors clustered at country level in parentheses. Significance levels: ${ }^{* *} \mathrm{p}<0.01, * *$ $\mathrm{p}<0.05,{ }^{*} \mathrm{p}<0.1$. All regressions include country and year fixed effects. 
Table 11: Results by Subperiods

\begin{tabular}{|c|c|c|c|c|}
\hline \multirow{3}{*}{$\begin{array}{l}\text { Dependent variable: CHAOS } \\
\text { Estimator: Negative Binomial }\end{array}$} & \multicolumn{4}{|c|}{ Subperiods } \\
\hline & 1919-1939 & 1946-1969 & 1970-1989 & 1990-2007 \\
\hline & $(1)$ & $(2)$ & $(3)$ & $(4)$ \\
\hline \multirow{2}{*}{$\Delta(\exp / \mathrm{GDP})$} & -0.039 & $-0.107 * * *$ & & \\
\hline & {$[0.035]$} & [0.029] & & \\
\hline \multirow[t]{2}{*}{$\Delta($ primary $\exp / G D P)$} & & & -0.067 & $-0.185^{* * *}$ \\
\hline & & & {$[0.083]$} & [0.068] \\
\hline \multirow[t]{2}{*}{$\Delta(\mathrm{GDP})$} & $-0.046^{* * *}$ & $0.066^{* * *}$ & $-0.096^{*}$ & $-0.291^{* * *}$ \\
\hline & {$[0.016]$} & {$[0.023]$} & {$[0.051]$} & {$[0.081]$} \\
\hline Observations & 238 & 346 & 239 & 283 \\
\hline Number of countries & 17 & 16 & 14 & 16 \\
\hline
\end{tabular}

Notes: Standard errors clustered at country level in parentheses. Significance levels:*** $\mathrm{p}<0.01$, ${ }^{* *} \mathrm{p}<0.05,{ }^{*} \mathrm{p}<0.1$. All regressions include country and year fixed effects.

Table 12: Alternative Measures of Unrest

\begin{tabular}{|c|c|c|c|c|c|c|}
\hline $\begin{array}{l}\text { Dependent variable } \\
\text { indicated in columns } \\
\text { Estimator: OLS }\end{array}$ & $\begin{array}{l}\text { Principal } \\
(1)\end{array}$ & $\begin{array}{c}\text { Componen } \\
(2)\end{array}$ & $\begin{array}{l}\text { Analysis } \\
(3)\end{array}$ & $\begin{array}{l}\text { Weighte } \\
(4)\end{array}$ & $\begin{array}{l}\text { ed Conflic } \\
(5)\end{array}$ & $\begin{array}{l}\text { Index } \\
\qquad(6)\end{array}$ \\
\hline$\Delta(\exp / G D P)$ & $\begin{array}{c}-0.054^{* *} \\
{[0.022]}\end{array}$ & & & $\begin{array}{l}-31.983 \\
{[24.649]}\end{array}$ & & \\
\hline$\Delta(r e v / G D P)$ & & $\begin{array}{c}0.000 \\
{[0.019]}\end{array}$ & & & $\begin{array}{c}16.266 \\
{[33.410]}\end{array}$ & \\
\hline$\Delta($ budget/GDP $)$ & & & $\begin{array}{c}0.051^{* *} \\
{[0.024]}\end{array}$ & & & $\begin{array}{c}49.802 \\
{[31.073]}\end{array}$ \\
\hline$\Delta(G D P)$ & $\begin{array}{l}-0.002 \\
{[0.028]}\end{array}$ & $\begin{array}{c}0.007 \\
{[0.033]}\end{array}$ & $\begin{array}{c}0.002 \\
{[0.032]}\end{array}$ & $\begin{array}{c}-5.107 \\
{[24.745]}\end{array}$ & $\begin{array}{c}-1.955 \\
{[29.395]}\end{array}$ & $\begin{array}{c}-8.118 \\
{[30.790]}\end{array}$ \\
\hline Observations & 1,310 & 1,259 & 1,253 & 1,310 & 1,259 & 1,253 \\
\hline R-squared & 0.123 & 0.115 & 0.121 & 0.128 & 0.123 & 0.126 \\
\hline Number of countries & 24 & 24 & 24 & 24 & 24 & 24 \\
\hline
\end{tabular}


Table 13: CHAOS as a Dichotomous Variable

\begin{tabular}{|c|c|c|c|}
\hline $\begin{array}{l}\text { Dependent variable: CHAOS dummy } \\
\text { Estimator: Logit }\end{array}$ & (1) & $(2)$ & $(3)$ \\
\hline$\Delta(\exp / G D P)$ & $\begin{array}{l}-0.040 \\
{[0.030]}\end{array}$ & & \\
\hline$\Delta(\operatorname{rev} / G D P)$ & & $\begin{array}{c}0.020 \\
{[0.049]}\end{array}$ & \\
\hline$\Delta($ budget $/ G D P)$ & & & $\begin{array}{l}0.088^{*} \\
{[0.045]}\end{array}$ \\
\hline$\Delta(G D P)$ & $\begin{array}{c}-0.048^{*} \\
{[0.026]}\end{array}$ & $\begin{array}{l}-0.039 \\
{[0.028]}\end{array}$ & $-0.050^{*}$ \\
\hline Observations & 1,295 & 1,244 & 1,238 \\
\hline Number of countries & 22 & 22 & 22 \\
\hline
\end{tabular}

Table 14: Unrest, Expenditure Cuts and Growth

\begin{tabular}{lcccc}
\hline \hline Dependent variable: CHAOS & \multicolumn{4}{c}{ Subsamples } \\
Estimator: Negative Binomial & $\begin{array}{c}\Delta \operatorname{Exp}>0 \\
(1)\end{array}$ & $\begin{array}{c}\Delta \operatorname{Exp}<0 \\
(2)\end{array}$ & $\begin{array}{c}\Delta \text { GDP }>0 \\
(3)\end{array}$ & $\begin{array}{c}\Delta \text { GDP }<0 \\
(4)\end{array}$ \\
\hline & 0.015 & $-0.078^{* *}$ & $-0.047^{* *}$ & -0.008 \\
$\Delta(\exp / G D P)$ & {$[0.023]$} & {$[0.035]$} & {$[0.023]$} & {$[0.029]$} \\
$\Delta(G D P)$ & $-0.041^{* *}$ & $-0.033^{*}$ & -0.017 & -0.070 \\
& {$[0.017]$} & {$[0.019]$} & {$[0.020]$} & {$[0.061]$} \\
Observations & 702 & 608 & 1,147 & 160 \\
Number of countries & 24 & 24 & 24 & 22 \\
\hline
\end{tabular}

Notes: Standard errors clustered at country level reported in parentheses. Significance levels:*** $\mathrm{p}<0.01,{ }^{* *} \mathrm{p}<0.05,{ }^{*} \mathrm{p}<0.1$. All regressions include country and year fixed effects. 
Table 15: Descriptive Statistics, EPCD Dataset

\begin{tabular}{|c|c|c|c|c|c|c|c|}
\hline Main issue: & Exp Cuts & Taxes & Economy & Labour & Ecology & Peace & Education \\
\hline Number of events & 901 & 246 & 8,677 & 8,117 & 797 & 1,987 & 531 \\
\hline \multicolumn{8}{|l|}{ Averages per event: } \\
\hline \multicolumn{8}{|l|}{ Protesters: } \\
\hline Total & 192,557 & 142,347 & 49,479 & 33,839 & 5,732 & 20,092 & 52,784 \\
\hline Arrested & .76 & 2 & 4.2 & 4.4 & 2 & 7.2 & 2.4 \\
\hline Injured & .36 & .54 & .3 & .28 & 0.7 & 1.1 & 1 \\
\hline \multicolumn{8}{|l|}{ Security forces: } \\
\hline Total & 81 & 108 & 36 & 34 & 44 & 152 & 144 \\
\hline Injured & .35 & .094 & .12 & 11 & .092 & .12 & 1.3 \\
\hline
\end{tabular}

Table 16: Protest events from EPCD, 1980-1995

\begin{tabular}{|c|c|c|c|}
\hline $\begin{array}{l}\text { Dependent variable: } \mathrm{N} \text { events } \\
\text { with main issue = Exp Cuts } \\
\text { Estimator: Negative Binomial }\end{array}$ & $(1)$ & $(2)$ & $(3)$ \\
\hline$\Delta($ primary $\exp /$ GDP $)$ & $\begin{array}{c}-0.214^{*} \\
{[0.124]}\end{array}$ & & \\
\hline$\Delta($ tot rev/GDP $)$ & & $\begin{array}{l}-0.164 \\
{[0.111]}\end{array}$ & \\
\hline$\Delta$ (primary budget/GDP $)$ & & & $\begin{array}{c}0.021 \\
{[0.051]}\end{array}$ \\
\hline$\Delta(\mathrm{GDP})$ & $\begin{array}{l}-0.134 \\
{[0.104]}\end{array}$ & $\begin{array}{l}-0.106 \\
{[0.096]}\end{array}$ & $\begin{array}{l}-0.097 \\
{[0.102]}\end{array}$ \\
\hline Lag unemployment rate & $\begin{array}{c}0.111 \\
{[0.103]}\end{array}$ & $\begin{array}{c}0.129 \\
{[0.100]}\end{array}$ & $\begin{array}{c}0.115 \\
{[0.100]}\end{array}$ \\
\hline Observations & 230 & 230 & 230 \\
\hline Number of countries & 16 & 16 & 16 \\
\hline
\end{tabular}


Table 17: Placebo test, 1980-1995

\begin{tabular}{|c|c|c|c|c|c|c|c|}
\hline \multirow{2}{*}{$\begin{array}{l}\text { Dependent variable } \\
\text { indicated in columns } \\
\text { Estimator: Negative Binomial }\end{array}$} & \multicolumn{7}{|c|}{ Protest Event Main Issue: } \\
\hline & $\begin{array}{c}\text { Exp Cuts } \\
(1)\end{array}$ & $\begin{array}{c}\text { Economy } \\
(2) \\
\end{array}$ & $\begin{array}{c}\text { Peace } \\
(3)\end{array}$ & $\begin{array}{c}\text { Labor } \\
(4)\end{array}$ & $\begin{array}{c}\text { Education } \\
(5)\end{array}$ & $\begin{array}{c}\text { Ecology } \\
(6)\end{array}$ & $\begin{array}{l}\text { All } \\
(7) \\
\end{array}$ \\
\hline \multirow[t]{2}{*}{$\Delta($ primary $\exp /$ GDP $)$} & $-0.214^{*}$ & 0.007 & 0.031 & 0.006 & -0.238 & -0.052 & 0.001 \\
\hline & {$[0.124]$} & {$[0.036]$} & {$[0.081]$} & {$[0.037]$} & {$[0.252]$} & {$[0.107]$} & {$[0.024]$} \\
\hline \multirow[t]{2}{*}{$\Delta(\mathrm{GDP})$} & -0.134 & 0.013 & 0.075 & 0.025 & 0.150 & -0.006 & -0.003 \\
\hline & {$[0.104]$} & {$[0.026]$} & {$[0.089]$} & {$[0.024]$} & {$[0.127]$} & {$[0.056]$} & {$[0.022]$} \\
\hline \multirow{2}{*}{ Lag unemployment rate } & 0.111 & 0.052 & 0.063 & 0.051 & $-0.298^{*}$ & 0.014 & 0.026 \\
\hline & {$[0.103]$} & {$[0.033]$} & {$[0.063]$} & {$[0.034]$} & {$[0.155]$} & {$[0.080]$} & {$[0.030]$} \\
\hline Observations & 230 & 230 & 230 & 230 & 230 & 230 & 230 \\
\hline Number of countries & 16 & 16 & 16 & 16 & 16 & 16 & 16 \\
\hline
\end{tabular}

Notes: Standard errors clustered at country level in parentheses. Significance levels: ${ }^{* *} \mathrm{p}<0.01,{ }^{* *} \mathrm{p}<0.05, * \mathrm{p}<0.1$. All regressions include country and year fixed effects. In all specifications we excluded one clear outlier: France in 1995. 